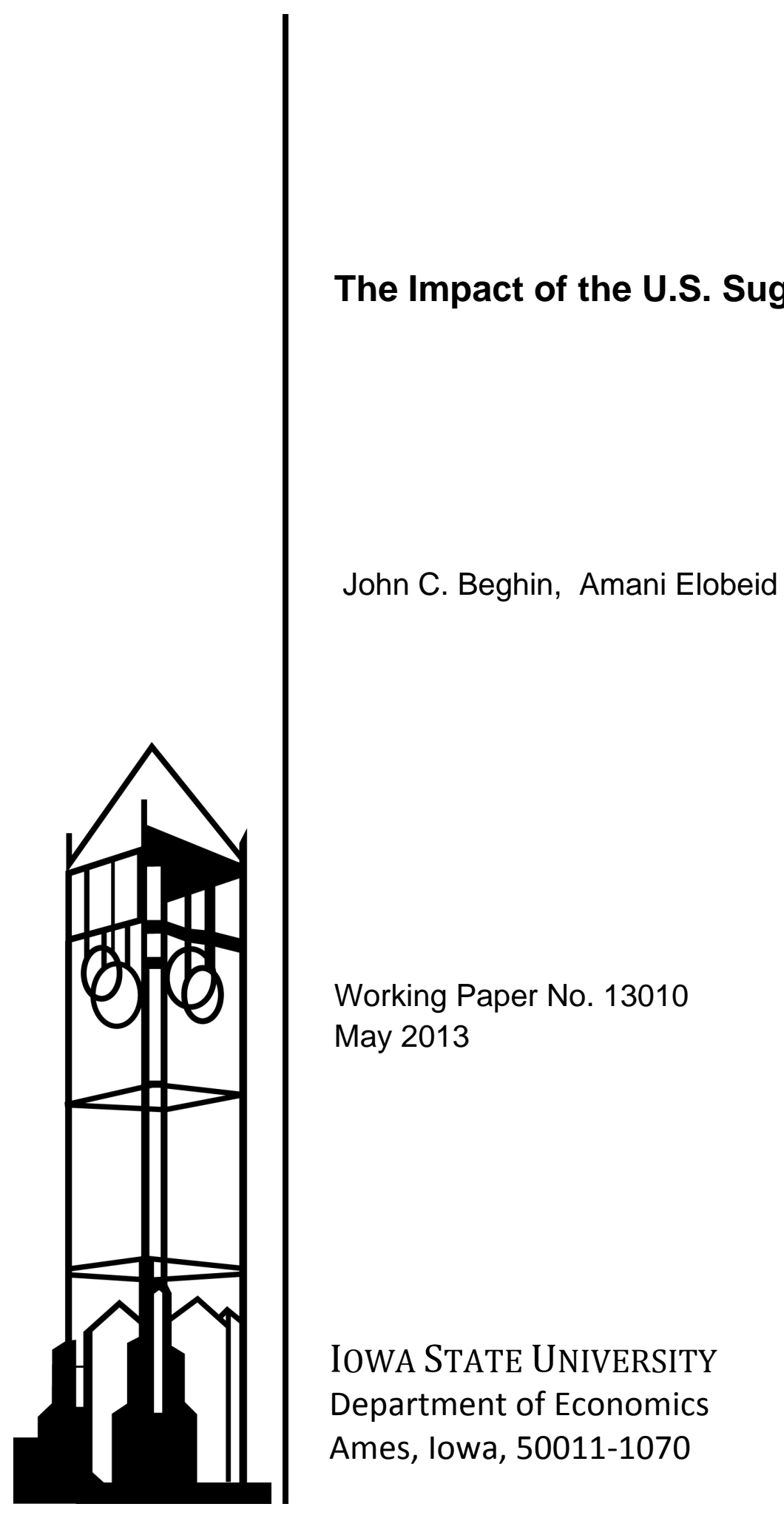

lowa State University does not discriminate on the basis of race, color, age, religion, national origin, sexual orientation, gender identity, genetic information, sex, marital status, disability, or status as a U.S. veteran. Inquiries can be directed to the Director of Equal Opportunity and Compliance, 3280 Beardshear Hall, (515) 294-7612. 


\title{
The Impact of the U.S. Sugar Program Redux
}

\author{
John Beghin and Amani Elobeid*
}

\section{Iowa State University}

May 2013

\begin{abstract}
We analyze the various welfare costs, transfers, trade, and employment consequences of the current U.S. sugar program for U.S. consumers, other sugar-users, sugar refiners, cane and beet growing and processing industries, other associated agricultural sectors, and world markets. The removal of the sugar program would increase U.S. consumers' welfare by $\$ 2.9$ to $\$ 3.5$ billion each year and generate a modest job creation of 17,000 to 20,000 new jobs in food manufacturing and related industries. Imports of sugar containing products would fall dramatically especially confectioneries substituting for domestic inputs under the sugar program. Sugar imports would rise substantially to 5 to 6 million short tons raw sugar equivalent. World price increases would be minor, equivalent to about 1 cent per pound.
\end{abstract}

Keywords: sugar program, tariff rate quota, welfare cost, employment effect, sugar containing products

JEL Code: Q17, Q18, F13

\footnotetext{
*Beghin is Marlin Cole Professor of International Agricultural Economics in the Economics Department at Iowa State University (ISU); Elobeid is a senior scientist at the Center for Agricultural and Rural Development at ISU. The Sweetener Users Association, an industry group seeking to reform the current U.S. sugar program, commissioned this independent analysis. The authors thank Tom Earley of Agralytica for helpful comments on earlier drafts and Remy Jurenas for discussions. The usual disclaimer applies. Corresponding author: Beghin, 383 Heady Hall, Economics ISU, Ames IA 50011-1070. beghin@iastate.edu.
} 


\section{Introduction}

The sugar industry in the United States has been heavily protected, even well before the federal sugar program was enacted in1934. As it stands today, the sugar program provides price guarantees to sugarcane and sugar beet producers through price support loans to sugar processors, marketing allotments limiting the quantity of sugar sold by each processor, import quotas, and a feedstock flexibility program for biofuel producers. ${ }^{1}$ The current program is administered by the U.S. Department of Agriculture (USDA) and authorized by the 2008 Farm Bill (Jurenas, 2013). This support of sugar producers has kept the U.S. sugar prices high, mostly two to three times higher than the world sugar price as is evident in Figure 1.

\section{Figure 1. U.S. and world raw sugar prices, fiscal year*}

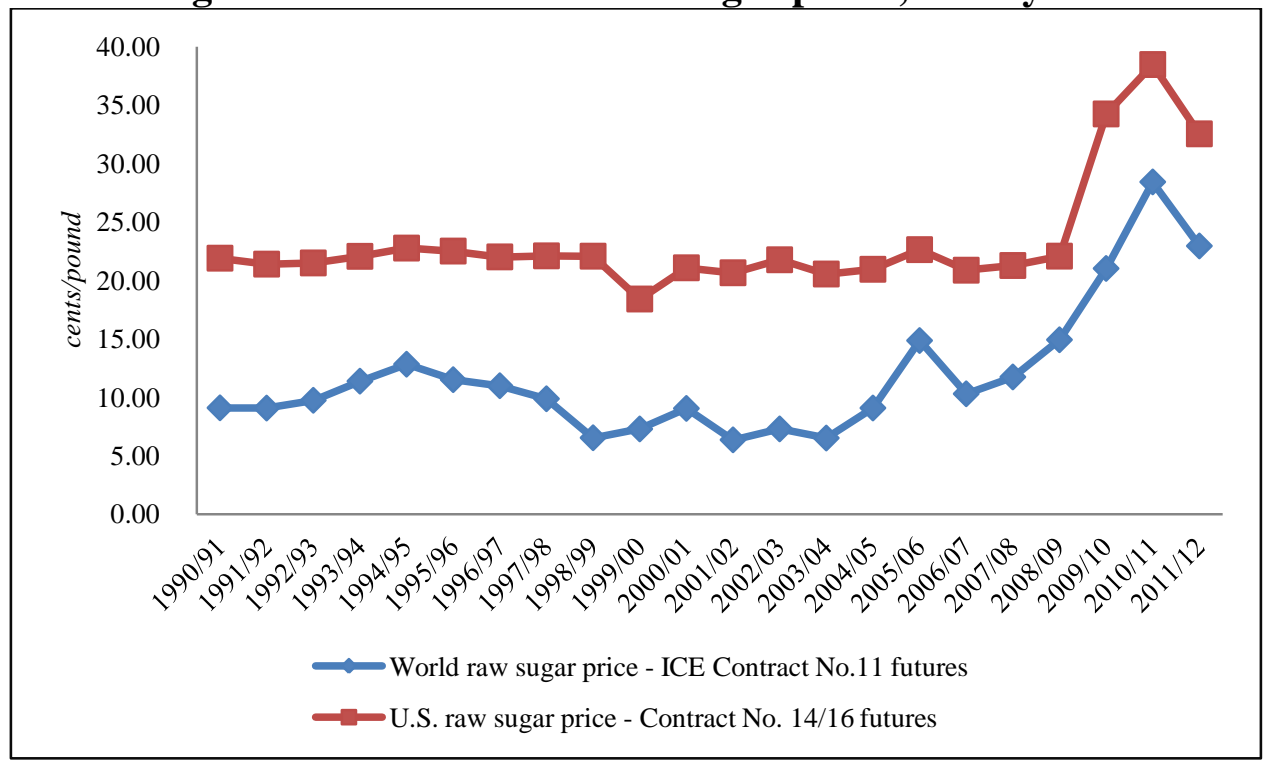

* Fiscal year is October through September. (Source: USDA/ERS, 2013a)

The U.S. grows both sugarcane and sugar beets for sugar production. Sugarcane is produced in Florida, Louisiana, Hawaii, and Texas. Sugar beets are grown in the Red River Valley (western Minnesota and eastern North Dakota), the Upper Great Plains (north central

\footnotetext{
${ }^{1}$ The overall allotment quantity is set each year by USDA at not less than $85 \%$ of estimated U.S. human consumption of sugar for food. Under the Feedstock Flexibility Program, the USDA is authorized to sell surplus sugar and sugar acquired under loan forfeitures to biofuel (ethanol) producers. Jurenas (2013) provides a concise description of the program.
} 
Wyoming, Montana, and western North Dakota), the Central Great Plains (southeastern

Wyoming, Colorado, and Nebraska), the Northwest (Idaho, Washington State, and portions of

Oregon), and the Far West (California). Figure 2 presents the sugar supply and use in the United States between 2000/01 and 2012/13. Sugar production averaged about 7.5 million metric tons, raw value over the last decade, with beet sugar making up about 60 percent of total production and sugarcane accounting for 40 percent. Sugar imports have been growing steadily, from 1.4 million metric tons in 2000/01 to about 3 million metric tons in 2012/13, to meet the domestic sugar demand not covered by domestic production.

Figure 2. U.S. supply and use, fiscal year

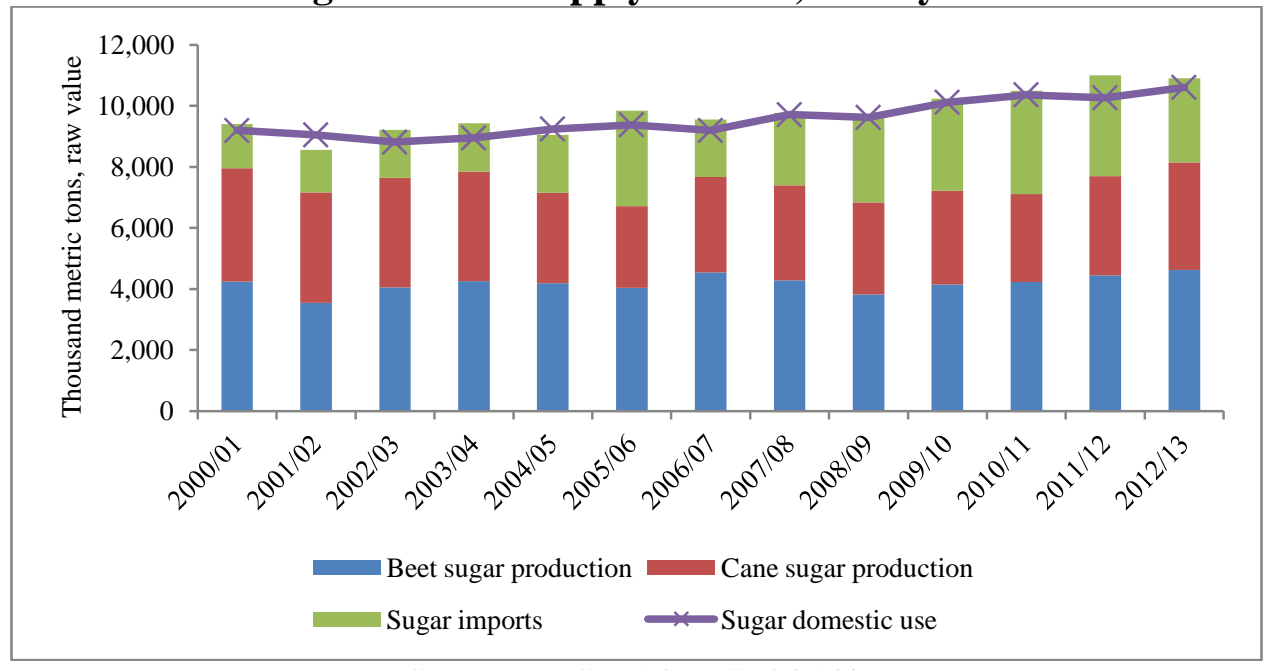

Source: USDA/ERS, 2013b

Despite the recent drop in the U.S. and world raw sugar prices from the historic levels in 2010/11, both prices remain high, with the U.S. price averaging 32.5 cents per pound in 2011/12 relative to the world's 22.9 cents per pound. Many have argued that, given the dramatic increase in world sugar prices and the negative effects of continued high sugar prices in the U.S., the sugar program should be abolished.

We present a new analysis of the various costs, transfers, and employment consequences of the current U.S. sugar program for U.S. consumers and other sugar-users, sugar refiners, cane 
and beet growing and processing industries, other associated agricultural sectors, and associated world markets. Many assessments of the sugar program exist in the context of a unilateral policy reform (Abler et al.; Beghin; Beghin et al., 2003; Orden; Orden et al.; USGAO; and Wohlgenant 2011) or as part of multilateral reforms (Elobeid and Beghin; Larson and Borrell; Mitchell; Van der Mensbrugghe et al.; and Wohlgenant, 1999). Three reasons motivate the analysis.

First, as mentioned above, world sugar prices have risen dramatically and are foreseen to remain high in the foreseeable future. This high price environment means that U.S. sugar producers would survive well under free trade, if such high world prices prevailed in domestic markets. These high world price levels tend to magnify the even much higher U.S. price level resulting from the current program. The second motivation for a new analysis relates to the employment effects of the sugar program. Although they have been debated (Promar 2011b), employment effects have not been formally analyzed. Last, imports of sugar containing products (SCPs) have expanded to circumvent the cost of the current sugar program and these imports have negatively affected economic activity in U.S. food processing sectors using sweeteners.

This paper is organized into five sections. Section 2 outlines the policy reform scenario. Section 3 provides the modeling approach with a description of the models utilized as well as the major model modifications required for this analysis. Section 4 presents the scenario results for the producers and end users of sugar and the impacts on employment, trade and taxpayers. The summary and conclusions are presented in Section 5.

\section{The Policy Reform Scenario}

Our analysis looks at the various impacts of removing the current program (price support, allotment) and moving to free trade in sugar as one way to assess the effects of current U.S. sugar policy as was done in the Government Accountability Office (GAO) and Wohlgenant 
analyses (USGAO; and Beghin et al. 2003; Wohlgenant, 2011). Looking at the complete elimination of the sugar program is a transparent way to estimate the various effects and transfers on all agents. Partial reforms have been investigated by Abler et al., Orden, and Orden et al., among others. As the sugar program is removed and borders opened, U.S. imports of sugar increase and U.S. sugar prices, raw and refined, fall to their world levels. Simultaneously, the increase in imports slightly increases world prices of sugar. U.S. sugar prices fall despite higher world prices.

In addition, it is assumed that to preserve acreage of cane and beet, cane and beet processors change their contractual arrangements with cane and beet growers to entice them to grow by offering them a larger share of the output price than the shares offered under the sugar program (see pages 9-10 for details). Last, the inventory behavioral equation is modified in the scenario; we reduce the response of inventories to the lower sugar price to moderate the magnitude of inventories to realistic levels under free trade.

The policy shocks are imposed on market projections from 2013 to 2020. The results are expressed in deviation from a baseline uniquely developed for the purpose of the analysis using an augmented FAPRI-ISU model approach, which derives and quantifies these effects in a consistent modeling framework. ${ }^{2}$ The approach encompasses both changes in raw and refined sugar prices. The difference between raw and refined prices has become an important development in recent years. U.S. refined sugar prices have exhibited a high margin above the U.S. raw sugar price. With trade liberalization, both prices decrease in the United States, but with a steeper decline for the refined sugar price than for the raw sugar price. Our baseline projection is consistent with the OECD-FAO and USDA baseline projections, in that in all three baselines,

\footnotetext{
${ }^{2}$ FAPRI-ISU is the Food and Agricultural Policy Research Institute at Iowa State University.
} 
world prices are expected to remain high for the foreseeable future. ${ }^{3}$ Trade flows are of comparable magnitudes.

\section{Modeling Approach}

\subsection{Major modeling steps}

This section presents the modeling steps in a non-technical exposition. A model appendix (appendix 1 available from the authors) provides more details and equations underlying the model. The model structure, described in more detail in the following section, is based on the FAPRI-ISU modeling system for raw sugar and sugar crops, biofuel, and associated crops, and an added U.S. food-processing sub-model specially developed for this analysis. This approach follows the spirit of the GAO analysis (USGAO; and Beghin et al.), which is expanded here to account for sugar-containing product (SCP) imports, and the effects of the sugar program and SCP trade on employment in key food processing industries intensive in sweeteners. The foodprocessing sub-model provides U.S. aggregate demands for refined sugar and High Fructose Corn Syrup (HFCS), which feed into the FAPRI-ISU models as arguments in the utilization of sugar and HFCS in the U.S. economy. The U.S. FAPRI-ISU models incorporate the important features of NAFTA. The models endogenize the world prices of raw sugar, U.S. prices of raw sugar and sugar crops, HFCS, corn and other crops linked to sugar production.

Beyond adding a U.S. food-processing module to the FAPRI-ISU models, modifications are made to account for the world supply of refined sugar and for the sugar use in foreign SCP goods imported into the United States, although these are small relative to world supplies. They are likely to have a small effect on world prices of sugar. The SCP trade has a potential substantial effect on the output and labor use of some food-processing sectors. World sugar

\footnotetext{
${ }^{3}$ OECD is the Organization for Economic Cooperation and Development. FAO is the Food and Agriculture Organization of the United Nations.
} 
balances are carefully accounted for consistency and accuracy. The standard FAPRI-ISU sugar model does not disaggregate raw and refined sugar. All sugars are expressed in raw sugar equivalent. We complement the existing FAPRI-ISU sugar model with an additional component to link the world price of refined sugar to the world price of raw sugar following the removal of the refined sugar TRQ in the United States. This point is explained in the world sugar model section below.

\subsection{The FAPRI-ISU modeling system}

The models used in this analysis are a sub-set of the models that are part of the FAPRI-ISU agricultural modeling system. This modeling system is comprised of international multi-market, partial-equilibrium, and non-spatial models as well as two country models for the U.S. and Brazil. The models are econometric and simulation models covering all major temperate crops, sugar, ethanol and biodiesel, dairy, and livestock and meat products for all major producing and consuming countries and are calibrated on a regular basis on most recently available data.

Extensive market linkages exist in these models, reflecting derived demand for feed in livestock and dairy sectors, competition for land in production, and consumer substitution possibilities for close substitutes such as vegetable oils and meat types. Agricultural and trade policies are included in the models to the extent that they affect the supply and demand decisions of the economic agents. Historical data are used to calibrate the models, and the models provide 10 or more years of projections for supply and utilization of commodities (namely, production, consumption, trade and stocks) as well as prices. Specifically for this analysis, the U.S. agricultural model, the U.S. cost of production model and the international sugar model were used. Given the importance of Brazilian sugar and ethanol in world sugar markets, the Brazilian agricultural model and the international ethanol model were also included. 


\subsubsection{Description of the U.S. sugar model}

The U.S. sugar model is embedded in the FAPRI-ISU U.S. agricultural model, a partialequilibrium model that includes behavioral equations to determine crop planted acreage, domestic feed, food and industrial uses, trade, and ending stocks in marketing years. ${ }^{4}$ The model solves for the set of prices that brings annual supply and demand into balance in all markets. For crops with by-products, behavioral equations for the by-products are also included, for example HFCS, ethanol and corn oil from corn, and soybean meal, soybean oil and biodiesel from soybeans. For each commodity, a market-clearing price is calculated at equilibrium

Specifically in the sugar module, the areas planted for sugarcane and sugar beet are modeled by major producing state and are a function of real own net returns, the real net returns of competing crops and sugar allotments. The latter have been mostly nonbinding under the 2008 farm bill since they are set much above actual production. They also do not influence the projections. Crop production is the product of the area harvested and trend yield. Using recovery rates, sugar beet and sugarcane production is converted to raw sugar equivalent.

Raw sugar demand is determined by the real sugar retail price, HFCS domestic deliveries, net imports of SCPs, real consumer expenditure and a trend. This demand is modified later to account for food processing sectors and the raw/refined sugar types (see following sections). Sugar stocks are a function of the raw sugar price and sugar production. Since the model is based on annual data, intra-year factors such as the fill rate of sugar TRQs are not easily accommodated. Exports are determined by the ratio of domestic to world sugar price and Mexican (NAFTA) sugar imports, which are determined in the international sugar model through a behavioral trade equation based on the relative Mexican to U.S. sugar price. Additionally,

\footnotetext{
${ }^{4}$ The U.S. agricultural model was initially developed and maintained by FAPRI at the University of MissouriColumbia. This analysis uses a modified version of this model.
} 
HFCS demand by Mexico is determined in the Mexico model and accounted for in HFCS exports in the U.S. model. ${ }^{5}$

The equilibrium domestic raw sugar price is achieved by equating supply and demand in the sugar market. Imports from countries other than Mexico are exogenous, reflecting the tariff rate quotas limiting U.S. imports of sugar from these countries. Other prices used in the model, namely the refined beet sugar price, the retail sugar price, the sugarcane price and the sugar beet price, are determined through price transmission equations based on the solved raw sugar price. Behavioral equations in the U.S. sugar model are explained in the modeling appendix along with the data sources for the variables.

The price received by beet farmers is based on a linear relationship between the wholesale price of refined sugar and the beet price. This represents the sharing of the beetprocessing margin. This distinction is somewhat contrived as beet farming and processing are vertically integrated in cooperatives owning the processing plants in all production areas. The aggregated returns to beet growing and processing often accrue to the same agents. The model keeps separate surplus measures for beet farmers and for the beet-processing sector. The linear relationship between the two prices is calibrated on the most recent available beet price and wholesale refined sugar price. Given the refined beet sugar price and the sugar beet price, the gross margin for beet sugar processors is computed. The sugar beet price is a function of the refined beet sugar price as farmers get a proportion of the refined price. Once support policies are removed, the prices of both refined beet sugar and the crop would decline and the impact on the gross margin in beet processing would be a reduction in the margins. In the scenario, we assume that the share of the sugar price captured by growers increases by $45 \%$ to entice planted

\footnotetext{
${ }^{5}$ The U.S. agricultural model includes supply and demand equations for HFCS and solves endogenously for the equilibrium HFCS price. This domestic HFCS price is linked to Mexico HFCS model equations to determine Mexico's demand for U.S. HFCS.
} 
acreage, which would otherwise decline considerably.

The gross margin of cane processors is a function of the price they receive for raw cane sugar and the price they pay for the cane crop. (Price of sugar*raw sugar per ton of cane) - Price paid for cane. Although the price received by cane farmers is directly linked to the raw sugar price, both prices vary. The cane price reflects the sharing agreement between growers and processors of cane. With sugar trade liberalization, both prices fall. The raw cane sugar prices fall by more than the cane crop price since the latter is assumed to represent a larger fraction of the raw sugar price. We assume that the share of the raw cane sugar price received by growers (and offered by processors) increases by $30 \%$ with trade liberalization to entice them to keep producing cane to be processed.

The markup between the raw and refined sugar prices is an instrumental parameter in the model since the refined price feeds back into the sugar demand and will influence model results once the sugar support policies are removed. The refined beet sugar price is a function of the raw sugar price. Historically, in the last 5 years (2007-2011), the price differential between the two prices ranged between 4.86 cents/lb and 17 cents/lb (non-adjusted for the raw/refined conversion). The model projects this differential to be about 15 cents/lb at the beginning of the projection period and about 14 cents/lb toward the end of the projection period in 2020. Margins in cane refining fall to 8 cents (non-adjusted) per pound in the scenario. Note that the 8-cent nonadjusted margin is equivalent to a little more than 6 cents adjusted for the raw/refined conversion (refined sugar price-1.07 raw sugar price).

\subsubsection{Description of the U.S. cost of production model}

Projections for variable costs of production for crops in the U.S. agricultural model are generated in a separate cost of production model. These costs are used to calculate the expected net returns 
for sugar beet and sugarcane used in the U.S. sugar model to determine planted area. These costs of production are also shown in appendix 1. Since data for sugarcane variable costs are not available from USDA, the sugarcane costs are determined by multiplying the sugar beet variable costs by 1.6, based on the relative field cost information for beet and cane production presented in USDA's January 2011 Sugar and Sweetener Outlook. Data sources are also provided in the same appendix.

The cost of production model then projects variable costs for sugar beet and sugarcane (and other crops) from 2008 to 2025 . For each of the cost components (seed, fertilizer, fuel, repairs, etc.), the projections are determined by the projected producer price index (PPI). Projections of price indices such as the PPI are obtained from IHS Global Insight. Once costs are determined and projected, the expected net returns for sugar beet and sugarcane can be calculated by state. The expected net returns then enter into the planted-area equations by state in the U.S. sugar model as explained above.

\subsubsection{Description of the international sugar model}

The international sugar model is a non-spatial, partial-equilibrium econometric world model consisting of several countries/regions, including a rest-of-the-world aggregate to close the model. Major sugar producing, exporting, and importing countries are included in the model. The model specifies only raw sugar production, use, and trade between countries/regions and does not disaggregate refined trade from raw trade. Consequently, there is no categorization between importers as refiners or toll refiners because the countries that specialize in that role are well known and stable over time.

The general structure of the country sub-model includes behavioral equations for area

harvested, yield, and production for sugar beet and sugar cane on the supply side, and per capita 
consumption and ending stocks for raw sugar on the demand side. Equilibrium prices, quantities, and net trade are determined by equating excess supply and excess demand across countries and regions. The sugar model uses price transmission equations to link the world and domestic markets for each country. Via the price transmission equations, the domestic price of each country or region is linked with a representative world price reported by USDA (currently ICE No 11 futures price). For the most recent historical year, the model uses recent nearby futures prices as USDA's reported price is not available.

We incorporate a world price of refined sugar to be linked to the consumption side of the model. We maintain a 5-cent difference per pound between the refined and raw sugar prices in the world market to express arbitrage in refining in world markets. As the world price of refined sugar is an FOB price quoted in non-U.S. ports, we add 3 cents of handling and transportation to account for the transaction cost between markets. In total 8 cents separate the raw and refined prices as landed at the United States border. For a given fixed world price of raw sugar, the perceived supply of refined sugar is horizontal at a price 8 cents above the raw sugar price (about 6 cents if accounting for $7 \%$ of sugar loss in the raw/refined conversion).

Planted area is modeled as a function of lagged planted area, lagged cane or beet sugar price, lagged prices of alternative crops, real fertilizer price, real livestock revenue and a trend. Yield is modeled as a function of lagged yield, the ratio of real sugar to fertilizer price, total area and a trend. The output to input price in the yield equation captures the potential intensification impact of prices, which reflects more intensive use of inputs such as fertilizer when revenue grows faster than cost. Total area captures the extensification impact, which reflects declining yield as more marginal land is brought into production. To complement the yield intensification specification, a fertilizer component is included in which growth in yield from a purely 
intensification effect is associated with a change in the rate of nitrogen-phosphorous-potassium (N-P-K) fertilizer application per hectare. Crop production is the product of planted area and yield. Total sugar production is obtained by converting beet and cane production into raw sugar equivalent.

Sugar consumption per capita is determined by the real consumer price of raw sugar and income per capita. Total demand is the product of per capita consumption and population. Inventory demand is a function of lagged ending stock, sugar consumption, and the real consumer price of raw sugar.

In many countries, the beet or cane prices are set by policy and can be treated as being predetermined. Some countries lack information on the agricultural price of raw sugar, so the real consumer price is used instead of the agricultural prices in the specification of the acreage response.

The excess demand (supply) of each country enters into the world market for raw sugar and the sum of all excess demands and supplies is equal to zero by market clearing to determine the world market price. Price transmission equations account for exchange rates and other price policy wedges, such as tariffs, and transfer-service margins. The typical price transmission equation assumes that agents in each country are price-takers in the world market. Countries are either natural importers or exporters if their autarkic price falls above or below the world price, respectively. Depending on data availability, domestic prices in the sugar model can be farm, wholesale, or retail prices. Because of the homogeneous nature of sugar, quality adjustments are not incorporated in the price transmission equations. In general, only one domestic price is used in the model. Consumer and producer prices are differentially specified only in countries that have a deficiency type of producer support or explicit tax on consumption. 
This general structure is slightly modified to accommodate policy interventions other than price distortions, such as quantitative restrictions on area, supply, or trade flows. For example, imports constrained by binding tariff rate quotas are treated as exogenous and domestic prices are solved endogenously. Policy interventions providing a price floor are treated as such and are effective whenever the domestic producer price falls to the price floor level. The interaction with other components of the FAPRI-ISU commodity models is limited to cross-price effects in supply (wheat, rice, and soybeans). There are no links in consumption. Data sources for the international sugar model are further described in the appendix.

\section{3. Major modifications to the FAPRI-ISU sugar models for this Analysis}

The allocation of final demand for sugar in the original FAPRI-ISU model is in raw sugar equivalent. It is the sum of raw cane sugar use (from imports and domestic production of both raw and refined cane sugar) and refined sugar from beet production. In the augmented model, the aggregate raw sugar use is split into refined sugar from cane plus sugar from beet (a perfect substitute for refined cane sugar), and raw sugar going as an input to sugar refining. The intermediate demand for refined sugar comes from food processing industries other than sugar industries. This intermediate demand is explained in the next section.

Among food industries processing sugar we distinguish NAICS sectors 311311 (Sugarcane Mills), 311312 (Cane Sugar Refining), and (311313 Beet Sugar Manufacturing) as the 3 sectors producing raw sugar and refined sugar (from raw cane sugar and beets) and employing workers. The sum of the production of sectors 3111312 and 311313 constitutes the total domestic production of refined sugar or sector 31131. This production, plus the imports of refined sugar, provides the total availability of refined sugar. Imported raw sugar goes into raw sugar refining and ends up as refined sugar. The food sectors modeled in the analysis are 
Breakfast cereal 31123, Sugar (refined) 31131, Choc \& confec. 31132, Confec. Mfg 31133, Nonchoc confec 31134, Frozen food 31141, Fruit \& Veg can 31142, Ice cream 31152, Bread \& Bakery 31181 , Cookies, cracker 31182, Snack food man 31191, Flavoring syrup 31193, and Soft drinks 31211. These sectors correspond to those selected in an analysis of employment effects of the sugar program by Promar International (Promar International, 2011a), with the addition of "sugar", which represents retail and food service demand for sugar.

\subsubsection{Modeling food processing industries}

We follow and update the approach of USGAO (2000) and more recently Miao et al. (2012) to model food processing industries. We extend these approaches by incorporating the trade of sugar-containing products (SCPs), an important source of trade diversion and indirect imports of sugar. These SCP imports are also a source of employment reduction in food industries, induced by reducing the production of SCPs at home.

The approach assumes constant-returns-to-scale technology and a price markup by food processors allowing for food prices to be above their unit cost. Constant returns imply that the cost per unit is equal to the marginal cost and equal to the sum of input prices weighted by their optimum level per unit of output. This structure implies that the change in unit cost is equal to the change in marginal cost. Whenever the sugar input price changes, the unit cost changes accordingly in a proportion equal to the sugar price change (in \%) weighted by the sugar input cost share. The price charged by food producers-retailers is set above unit cost with a fixed price markup (10 cents per 2007 constant dollar of retail, i.e., $\$ 1=\$ 0.1$ markup margin $+\$ 0.9$ unit cost). This approach abstracts from explicitly modeling the food wholesale and retail pricing behavior but acknowledges the markup. Under the assumption of constant markup, the decrease in sugar prices from removing the sugar program is transmitted to consumers of sweetenerintensive foods through lower input prices and thus output prices. Similarly, if the price of HFCS 
is affected by the change in sugar policy through some feedback effect via the demand for corn and the world corn price, the resulting change in the HFCS price translates into a similar proportional change in the food price.

The change in output in the food industries depends on the change in food demand and the change in trade of similar SCPs. Production is equal to domestic demand plus export demand net of imports. From this equality, changes in production output can be derived.

The intermediate demands for sweeteners in the U.S. are affected and follow from the constant-returns-to-scale assumption maintained for food processing. They are the sum of a scale effect coming from an expansion of food output after liberalization and the effects of lower input prices multiplied by the price elasticities of input demand with respect to sweetener prices. The sectoral sweetener input uses are aggregated over all food industries into total intermediate use of refined sugar and HFCS in food industries in the US.

With the sugar program removal, several SCP imports decrease and SCP exports increase because of the new parity between U.S. and world sugar prices; domestic food demand increases through lower food prices. These three effects summed up give the expansion of output in each of the 12 NAICS industries (other than sugar industries) analyzed in the investigation.

Imports of processed food are characterized by significant persistence and trade diversion to bypass the expensive sugar TRQ system. Some of these SCP imports vanish to a great extent without the sugar program rationale as they represent an uncompetitive way to bring in sugar or compete with domestic SCPs in the US under unfettered markets. Other SCP imports represent genuine trade integration and are little affected by changes in the sugar program. We account for the trade diversion in the modeling of SCP imports as described in appendix 1. Exports of SCPs do not show persistence (no clear time trend). The higher the US sugar price is relative to the 
world price, the less competitive these exports are. Hence we assume that food export demands respond negatively to the relative (US/world) price of raw sugar as shown in appendix 1.

\subsubsection{Food demand}

The approach to model food demand follows the approach used in the 2000 GAO study but considering traded goods with a market equilibrium condition including trade flows. The LINQUAD incomplete demand systems approach (LaFrance 1998) is flexible in its ability to reflect consumer preferences by incorporating the quadratic price term. The LINQUAD incomplete demand system approach is easy to calibrate while imposing proper curvature (Beghin et al., 2004) based on existing or consensus estimates of income and own-price elasticities. The system leads to an exact welfare measure for the final consumer. The specification of demand is linear in income and quadratic in food prices. The demands satisfy all traditional properties imposed on consumer demand systems.

When the sugar program is removed, new lower prices prevail for food since the unit cost of these food goods decreases as explained previously. These new prices lead to welfare gains measured by the equivalent variation $(\mathrm{EV})$ relative to original higher prices. The $\mathrm{EV}$ is interpreted as the dollar amount the consumer would have to be given to reach the same higher utility reached under free-trade prices, but under the higher food prices prevailing under the sugar program.

\subsubsection{Employment effects}

Employment effects follow from effects in food production sectors and are computed recursively because compensated labor demand hardly responds to sugar input prices. The price of labor is assumed constant because changes in these industries would be too small to influence wages. Labor is a derived demand for the labor input in the 13 NAICS industries (food processing 
sectors+ sugar industries). Labor is not a direct substitute for sweetener. To keep matters

transparent, we assume that labor use in NAICS industries depends on the scale of activities with constant return to scale technology. Total change in labor use in food processing industries is computed by aggregating the labor changes over all food industries of interest. The data on labor use come from US Census data, Survey of Manufacturers. Values are available for 2010. However, the last year detail material data are available for is 2007 , so we use labor data for 2007 as well to calibrate these labor effects consistently. We then recalibrate projections in 20082010 to match census data and then keep the same 2010 adjustment factor in later years (20132020).

\subsubsection{Return margins of food processors}

Each food processor/retailer marks up the unit cost of production to sell to consumers. Note that as we do not model retailers explicitly, we aggregate the retailing function with the processor sector. The FAPRI-ISU US sugar model provides a retail price of sugar so for that sector we can explicitly compute a retailer gross margin. Assuming the constant price margin (10 cents per dollar of retail food value in 2007 prices inclusive of the margin ( $\$ 1=0.1$ margin+0.9 unit cost)), then consumer prices fall by as many cents as the corresponding unit costs do. Consumers benefit from price decreases (in cents per unit) equivalent to the dollar cost savings experienced by food processors. The changes in returns margins (returns above cost) of the food processors/sellers are then equal to the price markup (10 cents in 2007 dollars) multiplied by the expansion of output.

\subsection{The calibration of the added food processing and consumer module}

The calibration is explained in detail in the model appendix. Here we summarize key points and a few changes undertaken after an evaluation of the initial calibration. This calibration of the 
demand system initially follows similar steps as in the robust approach of Miao et al. (2012), and uses data for 2007 for food shipments. We use a similar set of elasticities but modify the ownprice elasticity of final sugar demand and set it equal to -0.10. Miao et al. have a value of-0.30.

Retail prices are set initially equal to 1 dollar in 2007 prices, except for sugar, which is explained next. The $\$ 1$ prices then vary over time with various components. The cost of sweeteners reflects the use and unit cost of sugar and HFCS in the FAPRI-ISU projections. The other cost component grows with the food CPI. The return margin of 10 cents (in 2007 dollars) also grows nominally with the food CPI. Hence these nominal prices evolve during the projection period. Real prices are obtained by deflating income and prices by the general CPI recentered on 2007. Real prices increase over the baseline period because the food CPI is projected to grow faster than the general CPI.

The retail price of sugar comes from the FAPRI-ISU model where it is specified as being determined by the lagged retail price, and the current wholesale and raw sugar prices. We modified that equation in the FAPRI-ISU model to reduce the persistence (from the lagged price coefficient which is reduced to 0.1 and with a doubling of coefficient on wholesale and raw sugar prices). This modification means that changes in the wholesale price translate faster into changes in the retail price of sugar. This modification is incorporated in the new baseline. In the free trade scenario we constrain the retail-wholesale margin on refined sugar not to exceed its level (in cents per pound) in the baseline in the corresponding year. This is done to convey the expected strong competition in retailing sugar to consumers.

Regarding the calibration of intermediate demand for sugar in food processing, we set the own-price elasticities of the sweetener input demands to -0.2 and the cross prices elasticities to 0.1. This is consistent with the view that these input demands for raw inputs are price-inelastic. 
Finally, in calibrating SCP imports, we had to experiment and calibrate the import demands of several sectors with smaller price responses, which had been initially set too responsive. The historical data on SCP trade came from Agralytica. Agralytica also provided a transparent mapping of HS chapters into NAICS industries. We followed the latter for the most part in combination with the concordance between HS and NAICS provided by the US Census Bureau. For sectors not covered by HS chapters involving sugar, we impose the sugar intensity per dollar of the corresponding domestic food-processing sector. Similarly, SCP exports exhibit the same intensity as domestic sectors and an adjustment factor is added to calibrate the projected sugar content of SCP exports on historical data.

\section{Scenario Results}

We present the results for the scenario in deviation from the baseline established for the analysis for years 2013 to 2020 . The scenario is expressed in percentage change from the baseline. Results are presented in two sets of tables. Tables 1a-1c show the results for food processors, consumers, SCP imports, and employment effects. Tables $2 \mathrm{a}-2 \mathrm{~d}$ presents results for the cane and beet sectors, their processing and cane refining and sugar imports. Each table shows the baseline and scenario levels. The scenario levels are shown in appendix 2 (available upon request). ${ }^{6}$

\subsection{Key drivers}

The two key drivers of the scenario results are the arbitrage between the world and U.S. prices of raw sugar and a similar arbitrage between world and U.S. prices of refined sugar. The U.S. price of raw sugar falls by $24 \%$ to $34 \%$ (rounded) depending on the year of the projection. The wholesale refined sugar price falls by $32 \%$ to $40 \%$, and the retail refined sugar price falls by $26 \%$ to $33 \%$. These effects are net of the increase in the world price of sugar induced by larger

\footnotetext{
${ }^{6}$ There is also an appendix 3, available from the authors, that shows the macro economic variables used in the projections. These do not change between the baseline and the scenario.
} 
imports by the U.S. economy. The raw sugar price on the world market increases by $2 \%$ to $4 \%$ or by about 1 cent per pound. These U.S. price changes reduce the cost of sugar in food processing and sugar retailing with benefits accruing to food processors and consumers. However, they induce contracting margins for all U.S. sugar industries from sugar crops to refiners. Domestic sugar production (beet sugar and raw cane sugar) initially declines about $10 \%$ and then recovers to nearly unchanged. Consumption rises about $15 \%$. Imports rise about $80 \%$. Cane sugar refiners operate at full capacity using raw sugar imports as input. The U.S. shifts from being a net importer of sugar-containing products to being a net exporter. More detailed results follow for each sector.

\subsection{Food processors}

Food processors experience lower cost of production by a few percentage points translating into a $1 \%$ to $3 \%$ price decrease (rounded) for the 12 processed goods. These reductions are modest because sweeteners represent a small cost share in production cost. Nevertheless, these translate to an increase in demand for their food products. These expansion effects are amplified by changes in SCP trade. There is a substantial reduction of the SCP imports, which existed to bypass the sugar program and the high cost of sugar. In addition, there is an expansion of exports of food products, which become more competitive without the sugar program. These effects are particularly potent in two sectors (Chocolate \& Confectionery, and Non Chocolate Confectionery) for which output increases by $39 \%$ to $58 \%\left(1^{\text {st }}\right.$ sector) and $19 \%$ to $27 \%$ (2d sector). These sectors see imports nearly vanish with reductions of $88 \%$ and $86 \%$ in the later years of the projection period. Other import reductions are much more modest. In aggregate, the sugar equivalent of SCPs and other food imports falls by 37 to $58 \%$ during the projection period.

To compute return margins for food processor-retailers, we keep a constant 10 cents per 
dollar of shipments at 2007 prices. The expansion of the processors' margins is derived through the expansion of their output. Cost savings are assumed to be passed through to consumers. The food processors/retailers return margins increase by 770 to 975 million dollars at current prices depending on the projected year. The largest margin changes arise in the two confectionary sectors previously mentioned (see table 1c).

These sectors use more sugar input, which explains the expansion of the intermediate demand for sugar. The intermediate use increases through two effects: the lower price of refined sugar used as input for roughly $6 \%$ to $8 \%$, and more importantly through the expansion of output in all food sectors, summing up to roughly $18 \%$ to $23 \%$ increase in intermediate demand. The latter expansion is particularly important in the two confectionary sectors. The total increase in the intermediate use of sugar is between $25 \%$ and $30 \%$.

\subsection{Final consumers}

Large gains accrue to final consumers through lower retail prices for sugar and for food items intensive in sweeteners. The prices for the 12 food products included in the consumption basket fall modestly (see table 1b), but these small price changes inclusive of the lower retail sugar price translate into $\$ 9$ to $\$ 11$ (rounded) of welfare gains per consumer, and this multiplied by the whole U.S. population amounts to 2.929 to 3.501 billion dollars of consumer welfare gains (see table 1c). These consumer welfare effects are larger than those obtained in the USGAO analysis because the price changes (dollar differences) induced by the policy change are much larger in the 2013-2020 projection than they were in 1996 or 1998, the two years analyzed by the GAO investigation (Beghin et al., 2003). Our consumer welfare figures are very slightly larger than those of Wohlgenant (2011), and slightly smaller than the $\$ 4$ billion consumer cost estimated by Promar International (2011b) because the latter analysis used recent (2011) data when prices in 
the United States were at their highest level relative to their world price counterparts. Hence, our results are consistent with these reference figures.

\subsection{Employment effects}

Employment grows proportionally with the expansion of activities in the food processing sectors. In aggregate, the 12 sectors show between 17,000 and 20,000 (rounded) new jobs depending on the year projected (see table 1c). The sugar crop processing sectors see some contraction but sugar refining increases as cheap raw sugar imports get refined beyond the volume refined under the sugar program. The net effect on the sugar complex is modest from $-0.5 \%$ to $+5.4 \%$ changes in labor use depending on the year. The latter figures can be disaggregated into the employment effects in raw sugar production, refined cane sugar production, and beet refined sugar production. Raw cane sugar production loses between $1 \%$ and $12 \%$ of its employment base depending on the year; refined cane sugar increases its employment by $24 \%$; and refined beet sugar production loses between $2 \%$ and $11 \%$ of its employment, depending on the year projected. The net increase in employment inclusive of the sugar sectors remains in the 16,90020,100 range (rounded figures). The largest proportional job creations occur in the confectionery sectors because they exhibit the largest relative increases in output.

\subsection{Sugar industries}

\subsubsection{Sugar beet and sugarcane growing industries}

Historically, average net returns per cane acre have been around \$126/acre for the period 2006/7 to $2010 / 11$ which compares roughly to recent wheat returns per acre (average around \$124/acre based on latest FAPRI-ISU estimates for 2009/10 and 2010/11 and also based on estimated historical net returns in our model for 2006/7 to 2010/11). In more recent years (2009/10 and 2010/11) cane net returns have been higher averaging \$228/acre as estimated in our model. Beet 
net returns have been much higher than most other commodities at $\$ 672 /$ acre (as estimated in our model for 2006/7 to 2010/11). In particular, they have been historically above corn and soybean returns. FAPRI University of Missouri at Columbia reports recent net returns for corn and soybean for 2009/10 and 2010/11 averaging \$405/acre for corn and \$324/acre for soybean. We estimate beet return for the same years averaging $\$ 863 /$ acre. These informal comparisons are made under several caveats given different model assumptions, land quality differences, different variability over time and regional variation not considered here. Nevertheless they provide some relative magnitudes.

With the removal of the U.S. sugar support policy and the consequent reduction in the domestic sugar price, sugar harvested beet area falls by a percent change between $2 \%$ and $11 \%$ depending on the year projected (see table $2 b$ ). Given the partial lagged element in the price expectation (current and lagged prices enter the expectation), the beet area falls more at first and then recovers with slightly higher world prices in later years. Sugarcane harvested area also declines relative to the baseline, ranging between 1 and $12 \%$, with a similar pattern of larger reductions occurring with the partial lag in price expectation in early years and then a recovery of planted area in later years as world prices follow an upward pattern.

As shown in Table 2d, net returns fall in cane and beet growing. Sugar beet growers' net returns fall by $4 \%$ to $24 \%$ during the projection period, with the decreases being first pronounced and then tapering at the end of the projection period when world prices increase. The net returns of cane growers fall by $9.2 \%$ to $113 \%$ with similar patterns of strong decreases in early years and then a recovery of net returns later in the projection period. The variations in gross market revenues are less substantial, varying between $1 \%$ and $16 \%$ decreases for cane growers, and 2 to $14 \%$ decreases for beet growers. 


\subsubsection{Sugar industries}

Given the reductions in sugarcane and sugar beet production, beet sugar and raw cane sugar production decline by similar percent changes. The margins of beet processors deteriorate as they receive a lower refined sugar price and have to compensate growers to entice them to plant beets. The estimated decreases in their margin range between $50 \%$ and $61 \%$. Cane processors see their margins fall as well by $3 \%$ to $54 \%$. U.S. sugar refiners decrease their reliance on domestic raw sugar. However, sugar refiners expand their output by about $24 \%$ as imports of raw sugar can occur at lower prices once the border is open. Refiners expand their output up to their capacity (7.2 million tons of refined sugar). Refiners see their margins (output times per unit margin) affected by two opposite forces. The margin per unit of output deteriorates, as the lower price of raw sugar does not fully offset the reduction in the U.S. refined sugar price. The per-unit margin falls by 57 to $58 \%$ depending on the projected year. As their output expands by $24 \%$, U.S. refiners can offset some of the losses on the per-unit margin by selling much larger volumes of refined sugar. The total margin (output times per unit margin) still falls by about $47 \%$ to $48 \%$.

Although the declines in processor margins appear large in percentage terms, it needs to be kept in mind that these declines are relative to a baseline in which these industries' margins far exceed their historic averages, due to the operation of policies in the 2008 farm bill. In fact, the scenario results can also legitimately be interpreted as returning these margins to nearer their historic levels. The lower sugar price encourages more demand for sugar, with domestic deliveries increasing by changes ranging between $14 \%$ and $17 \%$ over the projection period relative to the baseline. These changes come from increased consumer demand for sugar, increased intermediate demand for sugar in food processing, the latter being driven by a substantial decrease in SCP net imports and increase in SCP exports. 
The impact on the gross margins of cane processors, cane refiners, and beet processors is summarized visually in Figure 3. The impact of the 2008 farm bill in FY 10-12 has been to increase gross margins for all sectors by roughly $\$ 4$ billion annually (average of $\$ 3.390$ billion for 2006/7-08/09 and $\$ 7.426$ billion for 2009/10-11/12). The reform scenario brings these gross margins well within their recent historical values (pre 2008 farm bill) from their recent peaks in 2011/12 to an average of $\$ 3.669$ billion for $2013-15$ and 3.984 billion for the whole projection period as margins improve in later years.

Figure 3. Gross margins in sugar processing and refining - history and scenario

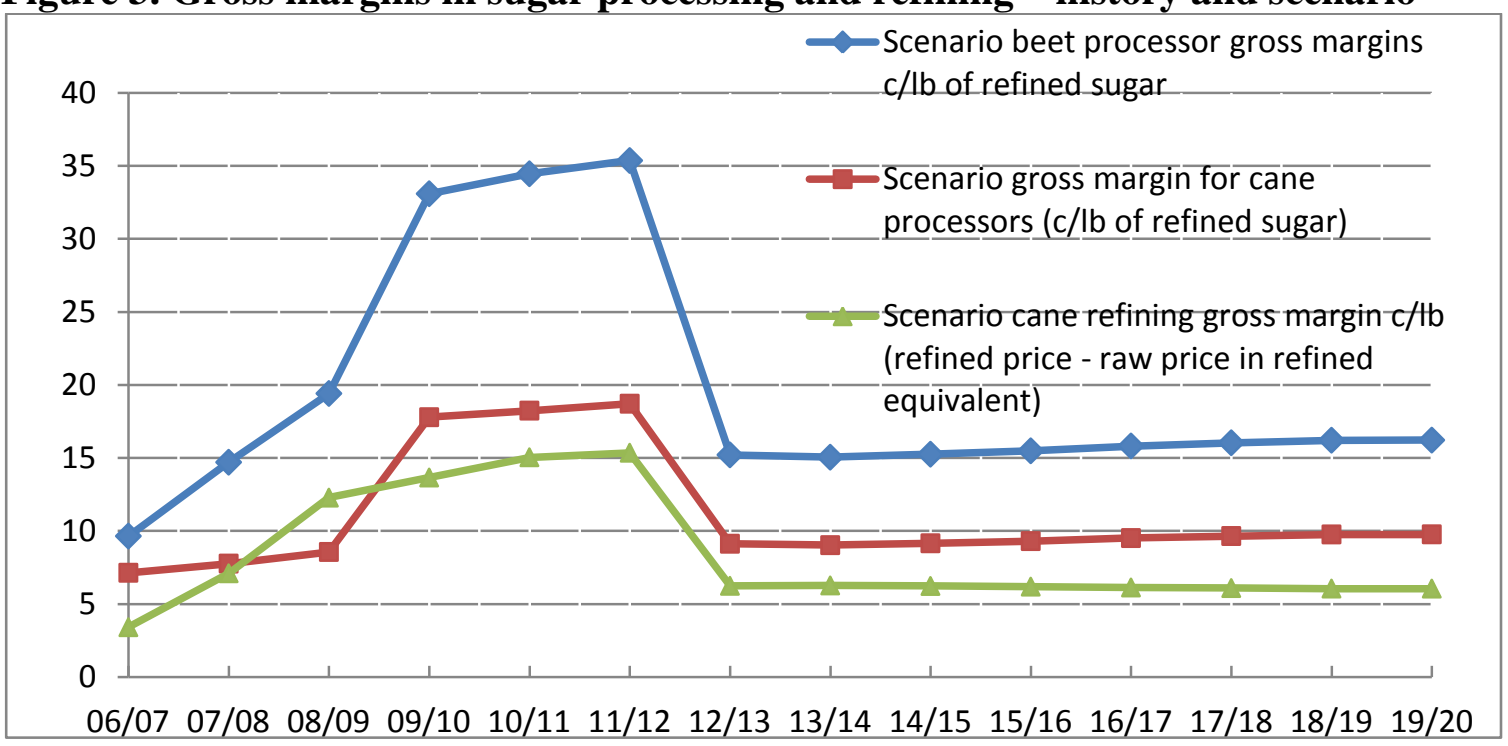

\subsection{HFCS sector}

HFCS producers see their gross margins deteriorate because the intermediate demand for HFCS falls as the sugar input use increases in food processing. HFCS use and output fall by $3 \%$ to $4 \%$. HFCS prices fall as a result by $3 \%$ to $6 \%$ depending on the year projected. Corn prices change little because the change in HFCS is very small relative to the total use of corn at the world level. The deterioration of HFCS margins comes solely from the decreases in output and output prices rather than from any effect on the input cost via changes in the price of corn, which is negligible. The total margins fall by 8 to $15 \%$ depending on the year projected. 


\subsection{Trade impact}

Trade impacts comprise two components, the SCP trade impact already discussed in the food processing section, and a second concerning sugar imports. To summarize the impact of SCP trade changes, the SCP import reductions correspond to the refined sugar equivalent of these imports to fall by $37 \%$ to $59 \%$; larger SCP exports lead to their sugar equivalent to rise by $12 \%$ to $20 \%$ during the projection period. Under free-trade, U.S. refiners would import a large amount of raw sugar to meet their capacity to optimize their processing margins and make up for the lower raw sugar production in the United States. Total sugar imports increase substantially, with increases between $52 \%$ and $84 \%$ depending on the year projected. Both refined and raw sugar imports increase because current domestic refining capacity and beet sugar production are not sufficient to satisfy domestic demand. Refined imports reach 1.53 million tons (strv) when beet sugar production bottoms and then decrease progressively to 755 thousand tons in 2020 , but are still well above baseline levels.

\subsection{Impact on taxpayers}

The impact on taxpayers comprises the impact on farm program outlays, import tax revenues and income and corporate taxes. All these effects are second-round effects and tend to be small by their very nature. The impact on farm policy program outlays of the removal of the sugar program is negligible. However, by eliminating the possibility of budget outlays under the Feedstock Flexibility Program, the policy changes would presumably eliminate several hundred million dollars in future taxpayer costs that are now projected in the Congressional Budget Office baseline to 2021 (roughly $\$ 50$ million annually from 2015 to 2021) (Hull, Langley, and Hitz (2011)).

As commodity prices remain high(er) under the scenario and as feedback from sugar crops to 
other crops is limited, there are no significant changes in domestic program outlays, which are made up of decoupled payments received independently from production. This abstracts from crop insurance and other insurance programs. The change in tariff revenues from SCP trade is limited as well as many of these imports originate in Mexico and Canada for which the applied duties are zero. The "spaghetti bowl" of regional trade agreement exemptions and heterogeneous rates complicates the computation of such effects beyond stating they are likely to be small.

\section{Summary and Conclusions}

We analyzed the consequences of eliminating all components of the U.S. sugar program, paying special attention to welfare, trade and employment. The elimination of the U.S. sugar program and the associated import quotas and tariffs beginning with the 2012/13 marketing year would result in significant decreases in domestic sugar prices and a resulting increase in use and reliance on sugar imports. U.S. sugar production would decline by about $10 \%$ during the first half of the projection period and then recovers to the 2011/12 level by 2020/21. Impacts on world market prices are moderate.

Domestic sugar deliveries would rise as U.S.-produced foods and beverages replace products that were formerly imported. The United States once again would become a net exporter of SCPs. Sugar imports would increase by 52\%-84\% during the projection period. U.S. cane sugar refiners would operate at full capacity throughout the period. Imports include both raw and refined sugar because we assumed no increase in cane sugar refining capacity.

Employment would grow with the expansion of activities in the food processing sectors. In aggregate, the 12 sectors show an expansion of between 17,000 and 20,000 new jobs depending on the year projected. The net effect on the sugar complex would be modest from $0.5 \%$ to $+5.4 \%$ changes in labor use depending on the year. 
We find a $\$ 2.9-3.5$ billion gain in consumer welfare caused by the lower sugar and food prices. This is about $\$ 10$ per person. This small individual amount is typical of rent seeking situations with diffuse losses for individual consumers and concentrated gains for producers. These gains are large in aggregate for the U.S. economy and they are explained by the high sugar prices prevailing in the period of analysis. Gross margins of sugar crop growers and processors had increased sharply with full implementation of the 2008 farm bill during 2009/10 - 2011/12. They were up by an average of $\$ 4.0$ billion per year to $\$ 7.4$ billion. With the reform, in the projection period they fall back closer to the $\$ 3.4$ billion average that prevailed during $2006 / 07$ 2008/09, averaging just below $\$ 4$ billion for 2012/13 to 2019/20.

In sum, the sugar program has become costlier over time because of its welfare, employment, and trade diversion consequences. The effective rent-seeking by the U.S. sugar industry can only explain why such a costly program has remained in place for so long.

\section{References}

Abler, D., Beghin, J. C., Blandford, D., \& Elobeid, A. 2008. Changing the US Sugar Program into a Standard Crop Program: Consequences under the North American Free Trade Agreement and Doha. Applied Economic Perspectives and Policy, 30(1), 82-102.

Beghin, J.C., J. Bureau, and S. Drogué. 2004. The Calibration of Incomplete Demand Systems in Quantitative Analysis. Applied Economics 36(8): 839-847.

Beghin, J., B. El Osta, J. Cherlow, and S. Mohanty. 2003. The Cost of the U.S. Sugar Program Revisited, Contemporary Economic Policy 21 (1) (2003): 106-116.

Beghin, J. 2007. "U.S. Sugar Policy: Analysis and Options," in B.L. Gardner and D. A. Sumner, eds., Agricultural Policy for the 2007 Farm Bill \& Beyond, AEI Press, American Enterprise Institute, 2007: 47-51.

Elobeid, A., \& Beghin, J. 2006. Multilateral trade and agricultural policy reforms in sugar markets. Journal of Agricultural Economics, 57(1): 23-48.

FAPRI-UMC. 2011. "FAPRI-MU August 2011 Baseline. Update for US Agricultural Markets FAPRI-MU Report \#10-11.

Hull D., J. Langley, and G. Hitz. 2011. "CBO March 2011 Baseline for CCC \& FCIC." Washington, D.C.: Congressional Budget Office.

Jurenas, Remy. 2013. "Sugar Program: The Basics." Congressional Research Service Report 75700. http://www.nationalaglawcenter.org/assets/crs/R42535.pdf, accessed April 17, 2013.

LaFrance, J.T. 1998. The LINQUAD Incomplete Demand Model. Working Paper, Department 
of Agricultural and Resource Economics, University of California, Berkeley.

Larson, D. F., \& Borrell, B. (2001). Sugar policy and reform (Vol. 2602). World Bank Publications.

Miao, Z., Beghin, J. C., \& Jensen, H. H. 2011. Taxing Sweets: Sweetener Input Tax or Final Consumption Tax?. Contemporary Economic Policy, 30(3): 344-361.

Mitchell, D.O. 2005. "Sugar Policies: An Opportunity for Change." Chapter 8 in M.A. Aksoy and J.C. Beghin, eds. Global Agricultural Trade and Developing Countries. World Bank Publications: 141-159.

Promar International. 2011a. Job Impacts of the Sugar Program. Mimeo.

Promar International. 2011b. US Sugar Policy Is Costing Consumers An Extra \$4 Billion Annually. Mimeo.

Orden, D. 2007. "Feasibility of Farm Program Buyouts: Is It a Possibility for U.S. Sugar?" In K.M. Huff, K.D. Meilke, R.D. Knutson, R.F. Ochoa, and J. Rude, eds., Achieving NAFTA Plus. Texas A\&M University, University of Guelph, and Inter-American Institute for Cooperation on Agriculture-Mexico.

Orden, D., Schmitz, A., Spreen, T. H., Messina Jr, W. A., \& Moss, C. B. (2002). Alternative sugar policies for the United States. In A. Schmitz, TH Spreen, WA Messina, and CB Moss, eds. Sugar and Related Sweetener Markets International Perspectives: 315-328.

U.S. Department of Agriculture, Economic Research Service (USDA/ERS). 2011. Sugar and Sweetener Outlook, ERS Electronic Outlook Report SSS-M-269, January 18.

U.S. Department of Agriculture. Economic Research Service (USDA/ERS). 2013a. "Table 3b: World Raw Sugar Price" and "Table 4: U.S. Raw Sugar Price", Sugar and Sweetener Yearbook Tables. http://www.ers.usda.gov/data-products/sugar-and-sweeteners-yearbooktables.aspx\#.UW8jdMo4qXk, accessed April 17, 2013.

U.S. Department of Agriculture, Economic Research Service (USDA/ERS). 2013b. "Table 24b: U.S. Sugar: Supply and Use (including Puerto Rico)", Sugar and Sweetener Yearbook Tables. http://www.ers.usda.gov/data-products/sugar-and-sweeteners-yearbooktables.aspX\#.UW8jdMo4qXk, accessed April 17, 2013.

USGAO. 2000. Sugar Program. Supporting Sugar Prices Has Increased Users' Cost While Benefiting Producers. Report GAO/RCED-00-126, June, Washington, D.C.

Van der Mensbrugghe, D., Beghin, J. C., \& Mitchell, D. O. (2003). Modeling tariff rate quotas in a global context: the case of sugar markets in OECD countries. Center for Agricultural and Rural Development, Iowa State University.

Wohlgenant, M.K. 2011. Sweets for the Sweet: The Costly Benefits of the US Sugar Program, American Boondoggle: Fixing the 2012 Farm Bill, American Enterprise Institute working paper.

Wohlgenant, M. K. 1999. "Effects of trade liberalization on the world sugar market." Mimeo, United Nations Food and Agriculture Organization (FAO). 
Table 1a. Baseline: Food Processing Sectors

\begin{tabular}{|c|c|c|c|c|c|c|c|c|}
\hline Year & 2013 & 2014 & 2015 & 2016 & 2017 & 2018 & 2019 & 2020 \\
\hline $\begin{array}{l}\text { Aggregate Sweetener measures } \\
\text { Refined sugar final demand }(1000 \\
\text { short ton }(\mathrm{st}))\end{array}$ & 4224 & 4279 & 4332 & 4388 & 4445 & 4503 & 4560 & 4617 \\
\hline $\begin{array}{l}\text { Total estimated refined sugar } \\
\text { from exports SCP }(1000 \mathrm{st})\end{array}$ & 588 & 587 & 591 & 599 & 610 & 617 & 623 & 625 \\
\hline $\begin{array}{l}\text { Total estimated refined sugar } \\
\text { from imports SCP }(1000 \mathrm{st})\end{array}$ & 1367 & 1380 & 1387 & 1385 & 1373 & 1358 & 1341 & 1327 \\
\hline $\begin{array}{l}\text { Intermediate demand refined } \\
\text { sugar }\end{array}$ & 3771 & 3828 & 3885 & 3949 & 4023 & 4098 & 4171 & 4242 \\
\hline $\begin{array}{l}\text { Total final }+ \text { intermediate demand } \\
\text { sugar }(1000 \text { short ton raw value })\end{array}$ & 8554 & 8675 & 8792 & 8920 & 9061 & 9204 & 9342 & 9480 \\
\hline $\begin{array}{l}\text { Total SCP net imports (imports- } \\
\text { exports) (1000 strv) }\end{array}$ & 834 & 849 & 851 & 841 & 817 & 792 & 769 & 752 \\
\hline $\begin{array}{l}\text { HFCS demand } \\
\text { Real food prices }\end{array}$ & 6830 & 6900 & 6960 & 7056 & 7153 & 7253 & 7337 & 7425 \\
\hline Breakfast cereal & 1.043 & 1.042 & 1.040 & 1.040 & 1.040 & 1.040 & 1.041 & 1.042 \\
\hline Sugar (refined) & 0.599 & 0.585 & 0.576 & 0.564 & 0.550 & 0.536 & 0.524 & 0.512 \\
\hline Chocolate and confectionery & 1.059 & 1.058 & 1.056 & 1.055 & 1.054 & 1.052 & 1.052 & 1.052 \\
\hline Confectionery manufacturing & 1.046 & 1.044 & 1.044 & 1.043 & 1.043 & 1.042 & 1.043 & 1.044 \\
\hline Non-chocolate confectionery & 1.054 & 1.053 & 1.052 & 1.050 & 1.049 & 1.048 & 1.048 & 1.048 \\
\hline Frozen food & 1.027 & 1.027 & 1.027 & 1.027 & 1.029 & 1.030 & 1.031 & 1.033 \\
\hline Fruits and Vegetables canning & 1.026 & 1.026 & 1.026 & 1.026 & 1.028 & 1.029 & 1.030 & 1.032 \\
\hline Ice cream & 1.032 & 1.031 & 1.031 & 1.031 & 1.032 & 1.032 & 1.034 & 1.035 \\
\hline Bread and Bakery & 1.034 & 1.034 & 1.033 & 1.033 & 1.034 & 1.034 & 1.036 & 1.037 \\
\hline Cookies, crackers & 1.043 & 1.042 & 1.042 & 1.041 & 1.041 & 1.041 & 1.042 & 1.043 \\
\hline Snack food man & 1.026 & 1.026 & 1.026 & 1.026 & 1.028 & 1.029 & 1.031 & 1.033 \\
\hline Flavoring syrup & 1.028 & 1.027 & 1.027 & 1.026 & 1.026 & 1.026 & 1.027 & 1.028 \\
\hline Soft drinks & 1.026 & 1.026 & 1.026 & 1.026 & 1.027 & 1.027 & 1.028 & 1.030 \\
\hline \multicolumn{9}{|l|}{ Total final demand } \\
\hline Breakfast cereal & 9758 & 9884 & 10025 & 10164 & 10295 & 10430 & 10562 & 10700 \\
\hline Sugar (refined) (million lbs) & 8448 & 8559 & 8664 & 8775 & 8891 & 9007 & 9120 & 9235 \\
\hline Chocolate and confectionery & 5725 & 5787 & 5852 & 5915 & 5975 & 6038 & 6097 & 6157 \\
\hline Confectionery manufacturing & 10124 & 10234 & 10348 & 10460 & 10566 & 10676 & 10782 & 10888 \\
\hline Non-chocolate confectionery & 6989 & 7065 & 7143 & 7221 & 7294 & 7370 & 7443 & 7516 \\
\hline Frozen food & 26366 & 26767 & 27232 & 27690 & 28106 & 28541 & 28962 & 29406 \\
\hline Fruits and Vegetables canned & 37160 & 37842 & 38644 & 39415 & 40063 & 40778 & 41422 & 42104 \\
\hline Ice cream & 9017 & 9132 & 9257 & 9379 & 9490 & 9607 & 9718 & 9832 \\
\hline Bread and Bakery & 37114 & 37594 & 38128 & 38658 & 39156 & 39669 & 40172 & 40696 \\
\hline Cookies, crackers & 19606 & 19860 & 20142 & 20422 & 20685 & 20956 & 21222 & 21498 \\
\hline Snack food manufacturing & 24743 & 25062 & 25418 & 25772 & 26104 & 26446 & 26781 & 27131 \\
\hline Flavoring syrup & 9001 & 9137 & 9296 & 9453 & 9595 & 9743 & 9887 & 10038 \\
\hline Soft drinks & 49636 & 50192 & 50760 & 51309 & 51802 & 52338 & 52820 & 53300 \\
\hline Year & 2013 & 2014 & 2015 & 2016 & 2017 & 2018 & 2019 & 2020 \\
\hline \multicolumn{9}{|l|}{$\begin{array}{l}\text { Exports of SCP food products } \\
(2007 \text { \$million) }\end{array}$} \\
\hline Breakfast cereal & 848 & 847 & 851 & 858 & 868 & 875 & 880 & 882 \\
\hline Chocolate and confectionery & 952 & 951 & 955 & 962 & 972 & 979 & 984 & 986 \\
\hline Non-chocolate confectionery & 401 & 400 & 404 & 411 & 421 & 428 & 433 & 435 \\
\hline Frozen food & 1373 & 1372 & 1376 & 1383 & 1393 & 1400 & 1405 & 1407 \\
\hline Fruits and Vegetables canned & 2645 & 2645 & 2645 & 2645 & 2645 & 2645 & 2645 & 2645 \\
\hline Ice cream & 57 & 57 & 57 & 58 & 59 & 60 & 60 & 60 \\
\hline Bread and Bakery & 733 & 732 & 736 & 743 & 753 & 760 & 765 & 767 \\
\hline Cookies, crackers & 376 & 375 & 380 & 386 & 396 & 403 & 408 & 410 \\
\hline Snack food man & 729 & 728 & 733 & 739 & 749 & 756 & 761 & 763 \\
\hline Flavoring syrup & 437 & 436 & 441 & 447 & 458 & 464 & 469 & 471 \\
\hline Soft drinks & 491 & 490 & 494 & 501 & 511 & 518 & 523 & 525 \\
\hline $\begin{array}{l}\text { Total estimated refined sugar from } \\
\text { SCP exports (1000 metric ton (mt)) }\end{array}$ & 533 & 533 & 537 & 543 & 554 & 560 & 565 & 567 \\
\hline
\end{tabular}




\begin{tabular}{|c|c|c|c|c|c|c|c|c|}
\hline Year & 2013 & 2014 & 2015 & 2016 & 2017 & 2018 & 2019 & 2020 \\
\hline \multicolumn{9}{|l|}{ SCP food imports (2007 \$million) } \\
\hline Breakfast cereal & 411 & 411 & 411 & 411 & 411 & 411 & 410 & 410 \\
\hline Chocolate and confectionery & 2349 & 2384 & 2404 & 2405 & 2384 & 2353 & 2318 & 2287 \\
\hline Non-chocolate confectionery & 1747 & 1769 & 1778 & 1771 & 1747 & 1715 & 1683 & 1656 \\
\hline Frozen food & 2630 & 2631 & 2627 & 2616 & 2596 & 2577 & 2560 & 2549 \\
\hline Fruits and Vegetables canned & 5030 & 5055 & 5075 & 5092 & 5105 & 5114 & 5121 & 5127 \\
\hline Ice cream & 42 & 42 & 43 & 43 & 43 & 43 & 43 & 43 \\
\hline Bread and Bakery & 2354 & 2363 & 2370 & 2375 & 2379 & 2382 & 2384 & 2386 \\
\hline Cookies, crackers & 673 & 673 & 673 & 672 & 670 & 668 & 667 & 665 \\
\hline Snack food man & 376 & 382 & 386 & 388 & 387 & 385 & 381 & 378 \\
\hline Flavoring syrup & 213 & 213 & 213 & 212 & 210 & 208 & 206 & 205 \\
\hline Soft drinks & 2312 & 2323 & 2331 & 2336 & 2338 & 2337 & 2336 & 2335 \\
\hline $\begin{array}{l}\text { Total estimated refined sugar } \\
\text { from imports SCP }(1000 \mathrm{mt})\end{array}$ & 1240 & 1253 & 1258 & 1257 & 1246 & 1232 & 1217 & 1204 \\
\hline \multicolumn{9}{|l|}{ Food production } \\
\hline Breakfast cereal & 11228 & 11354 & 11498 & 11644 & 11785 & 11927 & 12065 & 12204 \\
\hline Chocolate and confectionery & 3712 & 3739 & 3788 & 3857 & 3948 & 4048 & 4148 & 4241 \\
\hline Confectionery manufacturing & 9206 & 9316 & 9430 & 9542 & 9648 & 9759 & 9864 & 9971 \\
\hline Non-chocolate confectionery & 5867 & 5920 & 5994 & 6084 & 6192 & 6307 & 6417 & 6519 \\
\hline Frozen food & 25922 & 26322 & 26795 & 27271 & 27717 & 28178 & 28621 & 29078 \\
\hline Fruits and Vegetables canned & 37910 & 38568 & 39349 & 40104 & 40740 & 41445 & 42082 & 42759 \\
\hline Ice cream & 7664 & 7778 & 7903 & 8026 & 8138 & 8256 & 8367 & 8481 \\
\hline Bread and Bakery & 34609 & 35079 & 35610 & 36142 & 36645 & 37163 & 37669 & 38193 \\
\hline Cookies, crackers & 20050 & 20302 & 20589 & 20877 & 21152 & 21432 & 21704 & 21984 \\
\hline Snack food manufacturing & 25787 & 26100 & 26456 & 26815 & 27157 & 27508 & 27852 & 28206 \\
\hline Flavoring syrup & 8885 & 9020 & 9184 & 9348 & 9502 & 9660 & 9810 & 9964 \\
\hline Soft drinks & 43820 & 44365 & 44929 & 45479 & 45981 & 46524 & 47013 & 47496 \\
\hline Year & 2013 & 2014 & 2015 & 2016 & 2017 & 2018 & 2019 & 2020 \\
\hline \multicolumn{9}{|l|}{ Employment } \\
\hline Breakfast cereal & 13592 & 13766 & 13967 & 14171 & 14367 & 14564 & 14756 & 14950 \\
\hline Sugar & 13741 & 13738 & 13817 & 13875 & 13930 & 13997 & 14071 & 14160 \\
\hline Chocolate and confectionery & 7437 & 7483 & 7569 & 7690 & 7850 & 8026 & 8200 & 8364 \\
\hline Confectionery manufacturing & 25571 & 25913 & 26267 & 26615 & 26944 & 27287 & 27615 & 27945 \\
\hline Non-chocolate confectionery & 16770 & 16938 & 17172 & 17460 & 17802 & 18166 & 18516 & 18841 \\
\hline Frozen food & 91263 & 92665 & 94327 & 96000 & 97564 & 99185 & 100739 & 102343 \\
\hline Fruits and Vegetables canned & 85436 & 86974 & 88800 & 90565 & 92052 & 93702 & 95192 & 96773 \\
\hline Ice cream & 19255 & 19494 & 19755 & 20011 & 20244 & 20491 & 20723 & 20960 \\
\hline Bread and Bakery & 205907 & 208900 & 212284 & 215673 & 218880 & 222175 & 225401 & 228738 \\
\hline Cookies, crackers & 50218 & 50898 & 51673 & 52451 & 53194 & 53950 & 54687 & 55443 \\
\hline Snack food manufacturing & 44876 & 45471 & 46149 & 46831 & 47482 & 48151 & 48805 & 49478 \\
\hline Flavoring syrup & 6731 & 6832 & 6954 & 7077 & 7192 & 7309 & 7422 & 7537 \\
\hline Soft drinks & 69614 & 70425 & 71265 & 72084 & 72832 & 73640 & 74368 & 75088 \\
\hline Total employment with sugar & 650411 & 659498 & 670000 & 680502 & 690332 & 700644 & 710494 & 720619 \\
\hline Total employment without sugar & 636670 & 645760 & 656183 & 666627 & 676403 & 686647 & 696423 & 706459 \\
\hline
\end{tabular}


Table 1b. Scenario: Impact of the Removal of the U.S. Sugar Program on Food Processing Sectors (percent change from baseline levels)

\begin{tabular}{|c|c|c|c|c|c|c|c|c|}
\hline Year & 2013 & 2014 & 2015 & 2016 & 2017 & 2018 & 2019 & 2020 \\
\hline \multicolumn{9}{|l|}{ Aggregate Sweetener measures } \\
\hline Refined sugar final demand & $3.8 \%$ & $3.8 \%$ & $3.7 \%$ & $3.4 \%$ & $3.1 \%$ & $2.9 \%$ & $2.7 \%$ & $2.6 \%$ \\
\hline $\begin{array}{l}\text { Total estimated refined sugar from } \\
\text { exports SCP }\end{array}$ & $17.9 \%$ & $18.0 \%$ & $17.2 \%$ & $15.9 \%$ & $14.0 \%$ & $12.7 \%$ & $11.8 \%$ & $11.5 \%$ \\
\hline $\begin{array}{l}\text { Total estimated refined sugar from } \\
\text { imports SCP }\end{array}$ & $-37.4 \%$ & $-51.3 \%$ & $-56.4 \%$ & $-58.2 \%$ & $-58.6 \%$ & $-58.4 \%$ & $-58.0 \%$ & $-57.6 \%$ \\
\hline Intermediate demand refined sugar & $27.9 \%$ & $30.4 \%$ & $30.7 \%$ & $29.9 \%$ & $28.1 \%$ & $26.6 \%$ & $25.4 \%$ & $24.6 \%$ \\
\hline Total final + intermediate demand sugar & $15.2 \%$ & $16.3 \%$ & $16.5 \%$ & $16.0 \%$ & $15.0 \%$ & $14.2 \%$ & $13.5 \%$ & $13.2 \%$ \\
\hline Total SCP net imports (imports-exports) & $-79 \%$ & $-102 \%$ & $-111 \%$ & $-115 \%$ & $-117 \%$ & $-118 \%$ & $-119 \%$ & $-119 \%$ \\
\hline HFCS demand & $-1.7 \%$ & $-1.7 \%$ & $-1.6 \%$ & $-1.5 \%$ & $-1.3 \%$ & $-1.2 \%$ & $-1.1 \%$ & $-1.1 \%$ \\
\hline \multicolumn{9}{|l|}{ Real food prices } \\
\hline Breakfast cereal & $-1.44 \%$ & $-1.44 \%$ & $-1.38 \%$ & $-1.29 \%$ & $-1.17 \%$ & $-1.09 \%$ & $-1.02 \%$ & $-0.98 \%$ \\
\hline Sugar (refined) & $-32.4 \%$ & $-33.1 \%$ & $-32.6 \%$ & $-31.3 \%$ & $-29.3 \%$ & $-27.9 \%$ & $-26.8 \%$ & $-26.3 \%$ \\
\hline Chocolate and confectionery & $-2.66 \%$ & $-2.62 \%$ & $-2.54 \%$ & $-2.39 \%$ & $-2.17 \%$ & $-2.01 \%$ & $-1.89 \%$ & $-1.82 \%$ \\
\hline Confectionery manufacturing & $-1.61 \%$ & $-1.58 \%$ & $-1.53 \%$ & $-1.44 \%$ & $-1.30 \%$ & $-1.21 \%$ & $-1.13 \%$ & $-1.09 \%$ \\
\hline Non-chocolate confectionery & $-2.29 \%$ & $-2.22 \%$ & $-2.16 \%$ & $-2.03 \%$ & $-1.84 \%$ & $-1.70 \%$ & $-1.60 \%$ & $-1.55 \%$ \\
\hline Frozen food & $-0.13 \%$ & $-0.13 \%$ & $-0.12 \%$ & $-0.11 \%$ & $-0.10 \%$ & $-0.10 \%$ & $-0.09 \%$ & $-0.09 \%$ \\
\hline Fruits and Vegetables canning & $-0.08 \%$ & $-0.07 \%$ & $-0.07 \%$ & $-0.06 \%$ & $-0.06 \%$ & $-0.05 \%$ & $-0.05 \%$ & $-0.05 \%$ \\
\hline Ice cream & $-0.54 \%$ & $-0.52 \%$ & $-0.50 \%$ & $-0.47 \%$ & $-0.42 \%$ & $-0.39 \%$ & $-0.37 \%$ & $-0.35 \%$ \\
\hline Bread and Bakery & $-0.71 \%$ & $-0.70 \%$ & $-0.67 \%$ & $-0.63 \%$ & $-0.57 \%$ & $-0.53 \%$ & $-0.50 \%$ & $-0.48 \%$ \\
\hline Cookies, crackers & $-1.41 \%$ & $-1.39 \%$ & $-1.35 \%$ & $-1.27 \%$ & $-1.15 \%$ & $-1.06 \%$ & $-1.00 \%$ & $-0.96 \%$ \\
\hline Snack food manufacturing & $-0.05 \%$ & $-0.04 \%$ & $-0.04 \%$ & $-0.04 \%$ & $-0.04 \%$ & $-0.03 \%$ & $-0.03 \%$ & $-0.03 \%$ \\
\hline Flavoring syrup & $-0.34 \%$ & $-0.24 \%$ & $-0.22 \%$ & $-0.20 \%$ & $-0.18 \%$ & $-0.17 \%$ & $-0.16 \%$ & $-0.16 \%$ \\
\hline Soft drinks & $-0.13 \%$ & $-0.09 \%$ & $-0.08 \%$ & $-0.07 \%$ & $-0.06 \%$ & $-0.06 \%$ & $-0.06 \%$ & $-0.06 \%$ \\
\hline \multicolumn{9}{|l|}{ Total final demand } \\
\hline Breakfast cereal & $0.73 \%$ & $0.72 \%$ & $0.69 \%$ & $0.64 \%$ & $0.58 \%$ & $0.54 \%$ & $0.50 \%$ & $0.48 \%$ \\
\hline Sugar (refined) & $3.82 \%$ & $3.81 \%$ & $3.68 \%$ & $3.45 \%$ & $3.14 \%$ & $2.91 \%$ & $2.72 \%$ & $2.60 \%$ \\
\hline Chocolate and confectionery & $0.77 \%$ & $0.76 \%$ & $0.73 \%$ & $0.68 \%$ & $0.62 \%$ & $0.58 \%$ & $0.54 \%$ & $0.52 \%$ \\
\hline Confectionery manufacturing & $0.77 \%$ & $0.76 \%$ & $0.73 \%$ & $0.68 \%$ & $0.62 \%$ & $0.58 \%$ & $0.54 \%$ & $0.52 \%$ \\
\hline Non-chocolate confectionery & $0.77 \%$ & $0.76 \%$ & $0.73 \%$ & $0.68 \%$ & $0.62 \%$ & $0.58 \%$ & $0.54 \%$ & $0.52 \%$ \\
\hline Frozen food & $1.33 \%$ & $1.32 \%$ & $1.25 \%$ & $1.17 \%$ & $1.06 \%$ & $0.97 \%$ & $0.91 \%$ & $0.87 \%$ \\
\hline Fruits and Vegetables canned & $3.24 \%$ & $3.20 \%$ & $3.03 \%$ & $2.81 \%$ & $2.54 \%$ & $2.33 \%$ & $2.17 \%$ & $2.08 \%$ \\
\hline Ice cream & $1.30 \%$ & $1.29 \%$ & $1.23 \%$ & $1.15 \%$ & $1.04 \%$ & $0.96 \%$ & $0.90 \%$ & $0.86 \%$ \\
\hline Bread and Bakery & $0.73 \%$ & $0.72 \%$ & $0.69 \%$ & $0.64 \%$ & $0.58 \%$ & $0.54 \%$ & $0.50 \%$ & $0.48 \%$ \\
\hline Cookies, crackers & $0.73 \%$ & $0.72 \%$ & $0.69 \%$ & $0.64 \%$ & $0.58 \%$ & $0.54 \%$ & $0.50 \%$ & $0.48 \%$ \\
\hline Snack food manufacturing & $0.73 \%$ & $0.72 \%$ & $0.69 \%$ & $0.64 \%$ & $0.58 \%$ & $0.54 \%$ & $0.50 \%$ & $0.48 \%$ \\
\hline Flavoring syrup & $1.33 \%$ & $1.32 \%$ & $1.25 \%$ & $1.17 \%$ & $1.06 \%$ & $0.97 \%$ & $0.91 \%$ & $0.87 \%$ \\
\hline Soft drinks & $1.46 \%$ & $1.45 \%$ & $1.38 \%$ & $1.29 \%$ & $1.18 \%$ & $1.09 \%$ & $1.02 \%$ & $0.98 \%$ \\
\hline \multicolumn{9}{|l|}{ Exports of SCP food products } \\
\hline Breakfast cereal & $11.36 \%$ & $11.41 \%$ & $10.95 \%$ & $10.17 \%$ & $8.99 \%$ & $8.21 \%$ & $7.64 \%$ & $7.43 \%$ \\
\hline Confectionery manufacturing & $10.12 \%$ & $10.16 \%$ & $9.76 \%$ & $9.07 \%$ & $8.02 \%$ & $7.33 \%$ & $6.83 \%$ & $6.65 \%$ \\
\hline Frozen food & $24.02 \%$ & $24.15 \%$ & $23.06 \%$ & $21.24 \%$ & $18.52 \%$ & $16.77 \%$ & $15.53 \%$ & $15.07 \%$ \\
\hline Fruits and Vegetables canned & $7.01 \%$ & $7.04 \%$ & $6.77 \%$ & $6.31 \%$ & $5.60 \%$ & $5.13 \%$ & $4.79 \%$ & $4.66 \%$ \\
\hline Ice cream & $0.04 \%$ & $0.04 \%$ & $0.04 \%$ & $0.03 \%$ & $0.03 \%$ & $0.03 \%$ & $0.03 \%$ & $0.02 \%$ \\
\hline Bread and Bakery & $16.87 \%$ & $16.96 \%$ & $16.24 \%$ & $15.03 \%$ & $13.20 \%$ & $12.01 \%$ & $11.15 \%$ & $10.84 \%$ \\
\hline Cookies, crackers & $13.13 \%$ & $13.20 \%$ & $12.65 \%$ & $11.74 \%$ & $10.35 \%$ & $9.44 \%$ & $8.79 \%$ & $8.54 \%$ \\
\hline Snack food manufacturing & $25.59 \%$ & $25.74 \%$ & $24.55 \%$ & $22.59 \%$ & $19.67 \%$ & $17.80 \%$ & $16.46 \%$ & $15.98 \%$ \\
\hline Flavoring syrup & $13.20 \%$ & $13.27 \%$ & $12.72 \%$ & $11.80 \%$ & $10.41 \%$ & $9.49 \%$ & $8.83 \%$ & $8.59 \%$ \\
\hline Soft drinks & $22.02 \%$ & $22.14 \%$ & $21.15 \%$ & $19.51 \%$ & $17.05 \%$ & $15.46 \%$ & $14.32 \%$ & $13.91 \%$ \\
\hline
\end{tabular}


Table 1b (continued)

\begin{tabular}{|c|c|c|c|c|c|c|c|c|}
\hline Year & 2013 & 2014 & 2015 & 2016 & 2017 & 2018 & 2019 & 2020 \\
\hline $\begin{array}{l}\text { Total estimated refined sugar } \\
\text { from exports from SCP }\end{array}$ & $19.61 \%$ & $19.71 \%$ & $18.85 \%$ & $17.41 \%$ & $15.26 \%$ & $13.86 \%$ & $12.85 \%$ & $12.48 \%$ \\
\hline \multicolumn{9}{|l|}{ SCP food imports } \\
\hline Breakfast cereal & $-0.23 \%$ & $-0.35 \%$ & $-0.40 \%$ & $-0.41 \%$ & $-0.40 \%$ & $-0.37 \%$ & $-0.35 \%$ & $-0.33 \%$ \\
\hline Chocolate and confectionery & $-55.0 \%$ & $-75.9 \%$ & $-83.9 \%$ & $-86.9 \%$ & $-88.0 \%$ & $-88.3 \%$ & $-88.3 \%$ & $-88.3 \%$ \\
\hline Non-chocolate confectionery & $-56.2 \%$ & $-76.0 \%$ & $-82.9 \%$ & $-85.3 \%$ & $-86.0 \%$ & $-86.1 \%$ & $-86.0 \%$ & $-85.8 \%$ \\
\hline Frozen food & $-5.80 \%$ & $-8.71 \%$ & $-10.0 \%$ & $-10.4 \%$ & $-10.1 \%$ & $-9.59 \%$ & $-9.10 \%$ & $-8.76 \%$ \\
\hline Fruits and Vegetables canned & $-0.54 \%$ & $-1.01 \%$ & $-1.42 \%$ & $-1.74 \%$ & $-1.98 \%$ & $-2.16 \%$ & $-2.30 \%$ & $-2.41 \%$ \\
\hline Ice cream & $-0.63 \%$ & $-1.17 \%$ & $-1.62 \%$ & $-1.98 \%$ & $-2.23 \%$ & $-2.40 \%$ & $-2.53 \%$ & $-2.63 \%$ \\
\hline Bread and Bakery & $-0.10 \%$ & $-0.18 \%$ & $-0.24 \%$ & $-0.28 \%$ & $-0.30 \%$ & $-0.32 \%$ & $-0.32 \%$ & $-0.32 \%$ \\
\hline Cookies, crackers & $-2.27 \%$ & $-3.40 \%$ & $-3.91 \%$ & $-4.03 \%$ & $-3.90 \%$ & $-3.70 \%$ & $-3.50 \%$ & $-3.35 \%$ \\
\hline Snack food manufacturing & $-6.89 \%$ & $-12.6 \%$ & $-17.1 \%$ & $-20.6 \%$ & $-23.1 \%$ & $-24.9 \%$ & $-26.2 \%$ & $-27.2 \%$ \\
\hline Flavoring syrup & $-7.16 \%$ & $-10.8 \%$ & $-12.4 \%$ & $-12.8 \%$ & $-12.5 \%$ & $-11.9 \%$ & $-11.3 \%$ & $-10.9 \%$ \\
\hline Soft drinks & $-1.03 \%$ & $-1.83 \%$ & $-2.43 \%$ & $-2.83 \%$ & $-3.06 \%$ & $-3.17 \%$ & $-3.22 \%$ & $-3.23 \%$ \\
\hline $\begin{array}{l}\text { Total estimated refined sugar } \\
\text { from imports SCP }\end{array}$ & $-37.4 \%$ & $-51.3 \%$ & $-56.4 \%$ & $-58.2 \%$ & $-58.6 \%$ & $-58.4 \%$ & $-58.0 \%$ & $-57.6 \%$ \\
\hline Year & 2013 & 2014 & 2015 & 2016 & 2017 & 2018 & 2019 & 2020 \\
\hline \multicolumn{9}{|l|}{ Food production } \\
\hline Breakfast cereal & $1.50 \%$ & $1.49 \%$ & $1.42 \%$ & $1.32 \%$ & $1.18 \%$ & $1.08 \%$ & $1.01 \%$ & $0.97 \%$ \\
\hline Chocolate and confectionery & $38.6 \%$ & $52.2 \%$ & $56.8 \%$ & $57.5 \%$ & $56.1 \%$ & $54.0 \%$ & $51.8 \%$ & $49.9 \%$ \\
\hline Confectionery manufacturing & $0.85 \%$ & $0.84 \%$ & $0.80 \%$ & $0.75 \%$ & $0.68 \%$ & $0.63 \%$ & $0.59 \%$ & $0.57 \%$ \\
\hline Non-chocolate confectionery & $19.30 \%$ & $25.25 \%$ & $27.02 \%$ & $27.09 \%$ & $26.26 \%$ & $25.23 \%$ & $24.21 \%$ & $23.39 \%$ \\
\hline Frozen food & $2.32 \%$ & $2.58 \%$ & $2.60 \%$ & $2.50 \%$ & $2.30 \%$ & $2.12 \%$ & $1.97 \%$ & $1.87 \%$ \\
\hline Fruits and Vegetables canned & $3.25 \%$ & $3.28 \%$ & $3.16 \%$ & $2.98 \%$ & $2.75 \%$ & $2.56 \%$ & $2.42 \%$ & $2.34 \%$ \\
\hline Ice cream & $1.66 \%$ & $1.64 \%$ & $1.56 \%$ & $1.46 \%$ & $1.32 \%$ & $1.22 \%$ & $1.14 \%$ & $1.09 \%$ \\
\hline Bread and Bakery & $1.06 \%$ & $1.06 \%$ & $1.01 \%$ & $0.94 \%$ & $0.85 \%$ & $0.78 \%$ & $0.73 \%$ & $0.70 \%$ \\
\hline Cookies, crackers & $1.27 \%$ & $1.29 \%$ & $1.25 \%$ & $1.17 \%$ & $1.06 \%$ & $0.97 \%$ & $0.91 \%$ & $0.87 \%$ \\
\hline Snack food manufacturing & $1.17 \%$ & $1.25 \%$ & $1.26 \%$ & $1.24 \%$ & $1.17 \%$ & $1.12 \%$ & $1.08 \%$ & $1.06 \%$ \\
\hline Flavoring syrup & $2.61 \%$ & $2.66 \%$ & $2.57 \%$ & $2.40 \%$ & $2.16 \%$ & $1.98 \%$ & $1.84 \%$ & $1.76 \%$ \\
\hline Soft drinks & $1.92 \%$ & $1.95 \%$ & $1.90 \%$ & $1.80 \%$ & $1.65 \%$ & $1.54 \%$ & $1.45 \%$ & $1.40 \%$ \\
\hline \multicolumn{9}{|l|}{ Employment } \\
\hline Breakfast cereal & $1.72 \%$ & $1.71 \%$ & $1.63 \%$ & $1.51 \%$ & $1.35 \%$ & $1.23 \%$ & $1.15 \%$ & $1.10 \%$ \\
\hline Sugar & $0.99 \%$ & $-0.48 \%$ & $-0.19 \%$ & $0.85 \%$ & $2.54 \%$ & $3.93 \%$ & $4.97 \%$ & $5.44 \%$ \\
\hline Chocolate and confectionery & $33.76 \%$ & $45.69 \%$ & $49.84 \%$ & $50.55 \%$ & $49.41 \%$ & $47.70 \%$ & $45.89 \%$ & $44.32 \%$ \\
\hline Confectionery manufacturing & $0.95 \%$ & $0.94 \%$ & $0.89 \%$ & $0.83 \%$ & $0.76 \%$ & $0.70 \%$ & $0.65 \%$ & $0.63 \%$ \\
\hline Non-chocolate confectionery & $21.42 \%$ & $28.00 \%$ & $29.93 \%$ & $29.95 \%$ & $28.98 \%$ & $27.79 \%$ & $26.63 \%$ & $25.68 \%$ \\
\hline Frozen food & $2.31 \%$ & $2.57 \%$ & $2.60 \%$ & $2.49 \%$ & $2.29 \%$ & $2.11 \%$ & $1.96 \%$ & $1.87 \%$ \\
\hline Fruits and Vegetables canned & $3.37 \%$ & $3.40 \%$ & $3.27 \%$ & $3.09 \%$ & $2.84 \%$ & $2.65 \%$ & $2.50 \%$ & $2.41 \%$ \\
\hline Ice cream & $1.38 \%$ & $1.37 \%$ & $1.31 \%$ & $1.22 \%$ & $1.11 \%$ & $1.02 \%$ & $0.96 \%$ & $0.92 \%$ \\
\hline Bread and Bakery & $1.14 \%$ & $1.13 \%$ & $1.08 \%$ & $1.01 \%$ & $0.91 \%$ & $0.84 \%$ & $0.78 \%$ & $0.75 \%$ \\
\hline Cookies, crackers & $1.37 \%$ & $1.39 \%$ & $1.35 \%$ & $1.26 \%$ & $1.14 \%$ & $1.05 \%$ & $0.97 \%$ & $0.93 \%$ \\
\hline Snack food manufacturing & $1.28 \%$ & $1.36 \%$ & $1.37 \%$ & $1.35 \%$ & $1.28 \%$ & $1.22 \%$ & $1.17 \%$ & $1.15 \%$ \\
\hline Flavoring syrup & $2.57 \%$ & $2.63 \%$ & $2.54 \%$ & $2.37 \%$ & $2.13 \%$ & $1.95 \%$ & $1.81 \%$ & $1.73 \%$ \\
\hline Soft drinks & $1.80 \%$ & $1.83 \%$ & $1.78 \%$ & $1.69 \%$ & $1.55 \%$ & $1.45 \%$ & $1.36 \%$ & $1.32 \%$ \\
\hline Total employment with sugar & $2.61 \%$ & $2.93 \%$ & $2.99 \%$ & $2.93 \%$ & $2.80 \%$ & $2.68 \%$ & $2.58 \%$ & $2.50 \%$ \\
\hline Total employment without sugar & $2.65 \%$ & $3.01 \%$ & $3.06 \%$ & $2.98 \%$ & $2.81 \%$ & $2.66 \%$ & $2.53 \%$ & $2.44 \%$ \\
\hline
\end{tabular}


Table 1c. Impact of Removal of U.S. Sugar Program on Consumer Welfare and Processing Profits

\begin{tabular}{|c|c|c|c|c|c|c|c|c|}
\hline Year & 2013 & 2014 & 2015 & 2016 & 2017 & 2018 & 2019 & 2020 \\
\hline Increase in total number of jobs & 17005 & 19346 & 20031 & 19960 & 19355 & 18802 & 18304 & 18014 \\
\hline Increase in 12 food sector number of jobs & 16868 & 19411 & 20057 & 19842 & 19001 & 18252 & 17605 & 17244 \\
\hline Welfare of individual consumer current ( \$/person) & 10.80 & 10.84 & 10.71 & 10.29 & 9.58 & 9.08 & 8.71 & 8.56 \\
\hline Welfare of individual consumer (2007 \$/person) & 9.73 & 9.57 & 9.26 & 8.71 & 7.95 & 7.39 & 6.95 & 6.71 \\
\hline Total welfare of consumers (2007 \$billion) & 3.11 & 3.09 & 3.02 & 2.87 & 2.64 & 2.48 & 2.36 & 2.29 \\
\hline Total welfare of consumers (nominal \$billion) & 3.45 & 3.50 & 3.49 & 3.39 & 3.18 & 3.05 & 2.95 & 2.93 \\
\hline \multicolumn{9}{|l|}{ Food production margins (2007 \$million) } \\
\hline Breakfast cereal & 16.81 & 16.93 & 16.36 & 15.41 & 13.95 & 12.92 & 12.15 & 11.83 \\
\hline Chocolate and confectionery & 143.31 & 195.15 & 215.30 & 221.86 & 221.35 & 218.49 & 214.79 & 211.57 \\
\hline Confectionery manufacturing & 7.79 & 7.83 & 7.56 & 7.15 & 6.57 & 6.14 & 5.81 & 5.65 \\
\hline Non-chocolate confectionery & 113.22 & 149.47 & 161.96 & 164.80 & 162.58 & 159.10 & 155.38 & 152.47 \\
\hline Frozen food & 60.04 & 67.92 & 69.74 & 68.13 & 63.62 & 59.61 & 56.24 & 54.40 \\
\hline Fruits \& Vegetables canned & 123.29 & 126.33 & 124.24 & 119.66 & 111.93 & 106.15 & 101.70 & 99.90 \\
\hline Ice cream & 12.69 & 12.77 & 12.36 & 11.71 & 10.75 & 10.05 & 9.51 & 9.26 \\
\hline Bread and Bakery & 36.80 & 37.16 & 36.03 & 34.14 & 31.26 & 29.17 & 27.57 & 26.87 \\
\hline Cookies, crackers & 25.39 & 26.26 & 25.77 & 24.51 & 22.43 & 20.88 & 19.67 & 19.12 \\
\hline Snack food manufacturing & 30.18 & 32.52 & 33.35 & 33.21 & 31.88 & 30.90 & 30.10 & 29.89 \\
\hline Flavoring syrup & 23.16 & 24.03 & 23.61 & 22.47 & 20.55 & 19.12 & 18.01 & 17.50 \\
\hline Soft drinks & 84.30 & 86.59 & 85.15 & 81.75 & 75.98 & 71.59 & 68.14 & 66.58 \\
\hline $\begin{array}{l}\text { Change in return margins food processor except sugar sector } \\
\text { (2007 \$million) }\end{array}$ & 676.97 & 782.96 & 811.43 & 804.80 & 772.87 & 744.12 & 719.07 & 705.04 \\
\hline $\begin{array}{l}\text { Changes in return margins food processor except sugar sector } \\
\text { (current \$million) }\end{array}$ & 770.14 & 909.47 & 962.41 & 974.65 & 956.33 & 940.73 & 928.57 & 929.32 \\
\hline $\begin{array}{l}\text { Gains to sugar users (food processors + consumers) } \\
\text { (current \$billion) }\end{array}$ & 4.225 & 4.411 & 4.456 & 4.362 & 4.140 & 3.988 & 3.880 & 3.858 \\
\hline Gains to sugar users (2007 \$billion) & 3.790 & 3.873 & 3.831 & 3.674 & 3.417 & 3.223 & 3.074 & 2.999 \\
\hline
\end{tabular}


Table 2a. Baseline: U.S. Sugar Crops, Raw Sugar and HFCS Sectors

\begin{tabular}{|c|c|c|c|c|c|c|c|c|}
\hline Fiscal year & 2013 & 2014 & 2015 & 2016 & 2017 & 2018 & 2019 & 2020 \\
\hline \multicolumn{9}{|l|}{ Sugar beets } \\
\hline Harvested area (1,000 a.) & 1,107 & 1,099 & 1,095 & 1,087 & 1,083 & 1,079 & 1,076 & 1,075 \\
\hline Yield (tons/a.) & 28 & 29 & 29 & 29 & 30 & 30 & 30 & 31 \\
\hline Production (1,000 tons) & 31,265 & 31,388 & 31,642 & 31,772 & 31,981 & 32,231 & 32,494 & 32,820 \\
\hline \multicolumn{9}{|l|}{ Sugarcane } \\
\hline Harvested area (1,000 a.) & 860 & 836 & 828 & 821 & 810 & 800 & 792 & 784 \\
\hline Yield (tons/a.) & 31.6 & 31.9 & 32.2 & 32.4 & 32.7 & 32.9 & 33.2 & 33.5 \\
\hline Production $(1,000$ tons $)$ & 27,209 & 26,660 & 26,624 & 26,612 & 26,465 & 26,360 & 26,283 & 26,239 \\
\hline \multicolumn{9}{|l|}{ Raw sugar } \\
\hline Supply (1000 strv) & 13,528 & 13,574 & 13,668 & 13,736 & 13,801 & 13,883 & 13,973 & 14,075 \\
\hline Beginning stocks & 1,776 & 1,818 & 1,824 & 1,831 & 1,843 & 1,860 & 1,876 & 1,891 \\
\hline Production & 8,352 & 8,343 & 8,418 & 8,477 & 8,532 & 8,599 & 8,673 & 8,761 \\
\hline Beet sugar & 4,998 & 5,050 & 5,123 & 5,177 & 5,244 & 5,317 & 5,394 & 5,481 \\
\hline Cane sugar & 3,354 & 3,293 & 3,295 & 3,300 & 3,288 & 3,282 & 3,279 & 3,280 \\
\hline $\begin{array}{l}\text { Refined Production from } \\
\text { Cane (in refined value) }\end{array}$ & 5,824 & 5,820 & 5,821 & 5,816 & 5,809 & 5,802 & 5,796 & 5,790 \\
\hline Net imports & 3,401 & 3,413 & 3,426 & 3,428 & 3,426 & 3,424 & 3,423 & 3,423 \\
\hline Net raw imports for refining & 2,878 & 2,934 & 2,933 & 2,924 & 2,927 & 2,926 & 2,923 & 2,916 \\
\hline Refined imports & 523 & 479 & 493 & 505 & 499 & 498 & 501 & 508 \\
\hline \multicolumn{9}{|l|}{ Disappearance } \\
\hline Domestic deliveries & 11,710 & 11,750 & 11,837 & 11,893 & 11,941 & 12,006 & 12,082 & 12,169 \\
\hline $\begin{array}{l}\text { Ending stocks } \\
\text { Sugar-containing }\end{array}$ & 1,818 & 1,824 & 1,831 & 1,843 & 1,860 & 1,876 & 1,891 & 1,907 \\
\hline products Net imports & 834 & 849 & 851 & 841 & 817 & 792 & 769 & 752 \\
\hline \multicolumn{9}{|l|}{ High fructose corn syrup } \\
\hline Production & 9,413 & 9,462 & 9,503 & 9,576 & 9,657 & 9,735 & 9,808 & 9,885 \\
\hline Domestic use & 7,942 & 7,957 & 7,971 & 7,996 & 8,019 & 8,039 & 8,057 & 8,077 \\
\hline Net exports & 1,471 & 1,504 & 1,532 & 1,580 & 1,638 & 1,696 & 1,751 & 1,808 \\
\hline \multicolumn{9}{|l|}{ Prices } \\
\hline N.Y. spot raw sugar & 37.37 & 37.28 & 37.54 & 37.44 & 37.09 & 36.79 & 36.60 & 36.39 \\
\hline Refined beet sugar & 54.81 & 54.63 & 54.92 & 54.73 & 54.18 & 53.71 & 53.38 & 53.03 \\
\hline Retail refined sugar & 66.46 & 66.25 & 66.60 & 66.57 & 66.19 & 65.84 & 65.62 & 65.40 \\
\hline Cane sugar loan rate & 18.75 & 18.75 & 18.75 & 18.75 & 18.75 & 18.75 & 18.75 & 18.75 \\
\hline Beet sugar loan rate & 24.09 & 24.09 & 24.09 & 24.09 & 24.09 & 24.09 & 24.09 & 24.09 \\
\hline HFCS, $42 \%$ Midwest & 24.41 & 24.66 & 25.37 & 25.40 & 25.20 & 25.09 & 25.15 & 25.14 \\
\hline World sugar price & 24.03 & 23.86 & 24.43 & 25.09 & 26.06 & 26.71 & 27.23 & 27.30 \\
\hline
\end{tabular}


Table 2b. Comparison Scenario - Baseline: U.S. Sugar Crops, Raw Sugar and HFCS Sectors

\begin{tabular}{|c|c|c|c|c|c|c|c|c|}
\hline $\begin{array}{l}\text { October-September year } \\
\text { Fiscal year }\end{array}$ & $\begin{array}{r}12 / 13 \\
2013 \\
\end{array}$ & $\begin{array}{r}13 / 14 \\
2014 \\
\end{array}$ & $\begin{array}{r}14 / 15 \\
2015 \\
\end{array}$ & $\begin{array}{r}15 / 16 \\
2016 \\
\end{array}$ & $\begin{array}{r}16 / 17 \\
2017 \\
\end{array}$ & $\begin{array}{r}17 / 18 \\
2018 \\
\end{array}$ & $\begin{array}{r}18 / 19 \\
2019 \\
\end{array}$ & $\begin{array}{r}19 / 20 \\
2020 \\
\end{array}$ \\
\hline \multicolumn{9}{|l|}{ Sugar beets } \\
\hline Harvested area & $-10.3 \%$ & $-11.0 \%$ & $-10.3 \%$ & $-8.7 \%$ & $-5.9 \%$ & $-3.9 \%$ & $-2.3 \%$ & $-1.7 \%$ \\
\hline Yield & $-0.1 \%$ & $-0.1 \%$ & $-0.1 \%$ & $-0.1 \%$ & $0.0 \%$ & $0.0 \%$ & $0.0 \%$ & $0.0 \%$ \\
\hline Production & $-10.4 \%$ & $-11.1 \%$ & $-10.4 \%$ & $-8.7 \%$ & $-6.0 \%$ & $-3.9 \%$ & $-2.3 \%$ & $-1.7 \%$ \\
\hline \multicolumn{9}{|l|}{ Sugarcane } \\
\hline Harvested area & $-6.2 \%$ & $-12.0 \%$ & $-11.6 \%$ & $-9.6 \%$ & $-6.7 \%$ & $-3.9 \%$ & $-1.9 \%$ & $-0.8 \%$ \\
\hline Yield & $0.0 \%$ & $0.0 \%$ & $0.1 \%$ & $0.1 \%$ & $0.1 \%$ & $0.0 \%$ & $0.0 \%$ & $0.0 \%$ \\
\hline Production & $-6.1 \%$ & $-11.9 \%$ & $-11.6 \%$ & $-9.6 \%$ & $-6.7 \%$ & $-3.9 \%$ & $-1.9 \%$ & $-0.7 \%$ \\
\hline \multicolumn{9}{|l|}{ Raw sugar } \\
\hline Supply & $14.5 \%$ & $15.5 \%$ & $15.6 \%$ & $15.2 \%$ & $14.4 \%$ & $13.8 \%$ & $13.3 \%$ & $12.9 \%$ \\
\hline Beginning stocks & $0.0 \%$ & $11.0 \%$ & $9.8 \%$ & $9.4 \%$ & $9.0 \%$ & $8.6 \%$ & $8.5 \%$ & $8.3 \%$ \\
\hline Production & $-8.7 \%$ & $-11.4 \%$ & $-10.8 \%$ & $-9.0 \%$ & $-6.2 \%$ & $-3.9 \%$ & $-2.1 \%$ & $-1.3 \%$ \\
\hline Beet sugar & $-10.4 \%$ & $-11.1 \%$ & $-10.4 \%$ & $-8.7 \%$ & $-6.0 \%$ & $-3.9 \%$ & $-2.3 \%$ & $-1.7 \%$ \\
\hline Cane sugar & $-6.1 \%$ & $-11.9 \%$ & $-11.6 \%$ & $-9.6 \%$ & $-6.7 \%$ & $-3.9 \%$ & $-1.9 \%$ & $-0.7 \%$ \\
\hline $\begin{array}{l}\text { Refined Production from } \\
\text { Cane (in refined value) }\end{array}$ & $23.6 \%$ & $23.7 \%$ & $23.7 \%$ & $23.8 \%$ & $24.0 \%$ & $24.1 \%$ & $24.2 \%$ & $24.3 \%$ \\
\hline Net imports & $79.0 \%$ & $83.6 \%$ & $83.6 \%$ & $78.3 \%$ & $68.8 \%$ & $60.9 \%$ & $54.9 \%$ & $52.0 \%$ \\
\hline Net raw imports for refining & $58.3 \%$ & $63.7 \%$ & $63.3 \%$ & $61.4 \%$ & $58.4 \%$ & $55.5 \%$ & $53.5 \%$ & $52.6 \%$ \\
\hline Refined imports & $192.5 \%$ & $205.4 \%$ & $204.5 \%$ & $176.3 \%$ & $129.6 \%$ & $92.8 \%$ & $63.1 \%$ & $48.8 \%$ \\
\hline \multicolumn{9}{|l|}{ Disappearance } \\
\hline Domestic deliveries & $15.0 \%$ & $16.4 \%$ & $16.6 \%$ & $16.2 \%$ & $15.3 \%$ & $14.6 \%$ & $14.0 \%$ & $13.7 \%$ \\
\hline $\begin{array}{l}\text { Ending stocks } \\
\text { Sugar-containing } \\
\text { products }\end{array}$ & $11.0 \%$ & $9.8 \%$ & $9.4 \%$ & $9.0 \%$ & $8.6 \%$ & $8.5 \%$ & $8.3 \%$ & $8.2 \%$ \\
\hline Net imports & $-79.1 \%$ & $-102.5 \%$ & $-111.2 \%$ & $-114.7 \%$ & $-116.5 \%$ & $-117.7 \%$ & $-118.5 \%$ & $-119.0 \%$ \\
\hline \multicolumn{9}{|l|}{ High fructose corn syrup } \\
\hline Production & $-3.3 \%$ & $-3.7 \%$ & $-3.7 \%$ & $-3.5 \%$ & $-3.2 \%$ & $-2.9 \%$ & $-2.8 \%$ & $-2.7 \%$ \\
\hline Domestic use & $-3.7 \%$ & $-4.1 \%$ & $-4.2 \%$ & $-3.9 \%$ & $-3.6 \%$ & $-3.3 \%$ & $-3.1 \%$ & $-3.1 \%$ \\
\hline Net exports & $-1.0 \%$ & $-1.4 \%$ & $-1.4 \%$ & $-1.3 \%$ & $-1.3 \%$ & $-1.2 \%$ & $-1.0 \%$ & $-1.0 \%$ \\
\hline \multicolumn{9}{|l|}{ Prices } \\
\hline N.Y. spot raw sugar & $-32.8 \%$ & $-33.7 \%$ & $-32.7 \%$ & $-30.9 \%$ & $-27.9 \%$ & $-25.8 \%$ & $-24.1 \%$ & $-23.5 \%$ \\
\hline Refined beet sugar & $-39.6 \%$ & $-40.1 \%$ & $-39.4 \%$ & $-38.1 \%$ & $-35.9 \%$ & $-34.2 \%$ & $-33.0 \%$ & $-32.5 \%$ \\
\hline Retail refined sugar & $-32.4 \%$ & $-33.1 \%$ & $-32.6 \%$ & $-31.3 \%$ & $-29.3 \%$ & $-27.9 \%$ & $-26.8 \%$ & $-26.3 \%$ \\
\hline Cane sugar loan rate & $0.0 \%$ & $0.0 \%$ & $0.0 \%$ & $0.0 \%$ & $0.0 \%$ & $0.0 \%$ & $0.0 \%$ & $0.0 \%$ \\
\hline Beet sugar loan rate & $0.0 \%$ & $0.0 \%$ & $0.0 \%$ & $0.0 \%$ & $0.0 \%$ & $0.0 \%$ & $0.0 \%$ & $0.0 \%$ \\
\hline HFCS, $42 \%$ Midwest & $-5.6 \%$ & $-3.6 \%$ & $-3.2 \%$ & $-2.9 \%$ & $-2.6 \%$ & $-2.5 \%$ & $-2.5 \%$ & $-2.5 \%$ \\
\hline World sugar price & $4.5 \%$ & $3.7 \%$ & $3.5 \%$ & $3.2 \%$ & $2.6 \%$ & $2.3 \%$ & $2.0 \%$ & $1.9 \%$ \\
\hline
\end{tabular}


Table 2c. Baseline: U.S. Crop Producers \& Processors and Refiner Margins

\begin{tabular}{|c|c|c|c|c|c|c|c|c|}
\hline Marketing year & $12 / 13$ & $13 / 14$ & $14 / 15$ & $15 / 16$ & $16 / 17$ & $17 / 18$ & 18/19 & $19 / 20$ \\
\hline Gross margin beet processors $(1000 \$)$ & 3186590 & 3208104 & 3269914 & 3291965 & 3301398 & 3319296 & 3346563 & 3378911 \\
\hline Beet processor margins ( $\$ /$ ton of beet) & 101 & 101 & 102 & 103 & 102 & 102 & 102 & 102 \\
\hline $\begin{array}{l}\text { Beet processor margins (c/lb of refined } \\
\text { sugar) }\end{array}$ & 34 & 34 & 34 & 34 & 34 & 33 & 33 & 33 \\
\hline Gross margin cane processors (c/lb) & 19.37 & 19.32 & 19.43 & 19.38 & 19.22 & 19.08 & 18.99 & 18.90 \\
\hline Margin for cane processors $(1000 \$)$ & 1378074 & 1349762 & 1358269 & 1357030 & 1340808 & 1328614 & 1321071 & 1314695 \\
\hline $\begin{array}{l}\text { Margin per unit (refined price - raw } \\
\text { price in refined equivalence) (c/lb) }\end{array}$ & 15 & 15 & 15 & 15 & 14 & 14 & 14 & 14 \\
\hline Gross margin cane refiners $(1000 \$)$ & 1726490 & 1714928 & 1717653 & 1705944 & 1683526 & 1663626 & 1648016 & 1631834 \\
\hline \multicolumn{9}{|l|}{ Sugarcane returns } \\
\hline Gross market revenue (\$/acre) & 1312 & 1323 & 1348 & 1358 & 1357 & 1358 & 1363 & 1368 \\
\hline Variable expenses (\$/acre) & 1101 & 1135 & 1157 & 1186 & 1206 & 1224 & 1243 & 1262 \\
\hline Net returns $(\$ /$ acre $)$ & 211 & 188 & 190 & 172 & 151 & 134 & 120 & 106 \\
\hline \multicolumn{9}{|l|}{ Sugar beet returns } \\
\hline Gross market revenue (\$/acre) & 1747 & 1773 & 1817 & 1843 & 1855 & 1871 & 1892 & 1911 \\
\hline Variable expenses (\$/acre) & 688 & 709 & 723 & 741 & 754 & 765 & 777 & 789 \\
\hline Net returns $(\$ /$ acre $)$ & 1059 & 1064 & 1093 & 1101 & 1101 & 1106 & 1114 & 1123 \\
\hline HFCS gross margin (total) $(1000 \$)$ & 2144424 & 2213686 & 2273330 & 2325181 & 2304675 & 2303232 & 2319309 & 2364112 \\
\hline HFCS (per unit) (c/lb) & 15.84 & 16.11 & 16.51 & 16.62 & 16.40 & 16.28 & 16.28 & 16.35 \\
\hline
\end{tabular}

Table 2.d. Comparison (Scenario - Baseline) for U.S. Crop Producers \& Refiner Margins (in \% from baseline)

\begin{tabular}{|c|c|c|c|c|c|c|c|c|}
\hline Marketing year & $12 / 13$ & $13 / 14$ & $14 / 15$ & $15 / 16$ & $16 / 17$ & $17 / 18$ & $18 / 19$ & $19 / 20$ \\
\hline Gross margin for beet processors & $-60.1 \%$ & $-60.6 \%$ & $-60.0 \%$ & $-58.4 \%$ & $-55.8 \%$ & $-53.8 \%$ & $-52.3 \%$ & $-51.6 \%$ \\
\hline Beet processor margins & $-55.6 \%$ & $-55.9 \%$ & $-55.5 \%$ & $-54.6 \%$ & $-53.2 \%$ & $-52.2 \%$ & $-51.3 \%$ & $-51.0 \%$ \\
\hline Beet processor margins & $-55.4 \%$ & $-55.7 \%$ & $-55.3 \%$ & $-54.5 \%$ & $-53.0 \%$ & $-52.0 \%$ & $-51.2 \%$ & $-50.8 \%$ \\
\hline Gross margin for cane processors & $-49.6 \%$ & $-50.0 \%$ & $-49.6 \%$ & $-48.6 \%$ & $-47.0 \%$ & $-45.9 \%$ & $-45.0 \%$ & $-44.7 \%$ \\
\hline Margin for cane processors & $-50.8 \%$ & $-54.3 \%$ & $-53.6 \%$ & $-51.6 \%$ & $-48.5 \%$ & $-45.7 \%$ & $-43.6 \%$ & $-42.6 \%$ \\
\hline $\begin{array}{l}\text { Margin per unit (refined price - raw } \\
\text { price in refined equivalence) }\end{array}$ & $-57.9 \%$ & $-57.5 \%$ & $-57.8 \%$ & $-57.8 \%$ & $-57.7 \%$ & $-57.5 \%$ & $-57.4 \%$ & $-57.0 \%$ \\
\hline Gross margin for cane refiners & $-47.9 \%$ & $-47.4 \%$ & $-47.8 \%$ & $-47.8 \%$ & $-47.6 \%$ & $-47.3 \%$ & $-47.1 \%$ & $-46.6 \%$ \\
\hline \multicolumn{9}{|l|}{ Sugarcane returns } \\
\hline Gross market revenue & $-14.8 \%$ & $-16.0 \%$ & $-14.5 \%$ & $-11.8 \%$ & $-7.3 \%$ & $-4.0 \%$ & $-1.5 \%$ & $-0.7 \%$ \\
\hline Variable expenses & $0.0 \%$ & $0.0 \%$ & $0.0 \%$ & $0.0 \%$ & $0.0 \%$ & $0.0 \%$ & $0.0 \%$ & $0.0 \%$ \\
\hline Net returns & $-92.2 \%$ & $-113.0 \%$ & $-102.7 \%$ & $-93.0 \%$ & $-65.8 \%$ & $-41.0 \%$ & $-17.6 \%$ & $-9.2 \%$ \\
\hline \multicolumn{9}{|l|}{ Sugar beet returns } \\
\hline Gross market revenue & $-13.7 \%$ & $-14.4 \%$ & $-13.4 \%$ & $-11.2 \%$ & $-7.7 \%$ & $-5.1 \%$ & $-3.1 \%$ & $-2.3 \%$ \\
\hline Variable expenses & $0.0 \%$ & $0.0 \%$ & $0.0 \%$ & $0.0 \%$ & $0.0 \%$ & $0.0 \%$ & $0.0 \%$ & $0.0 \%$ \\
\hline Net returns & $-22.6 \%$ & $-24.0 \%$ & $-22.2 \%$ & $-18.8 \%$ & $-13.0 \%$ & $-8.6 \%$ & $-5.2 \%$ & $-3.8 \%$ \\
\hline HFCS gross margin(total) & $-14.7 \%$ & $-10.8 \%$ & $-10.1 \%$ & $-9.3 \%$ & $-8.4 \%$ & $-8.0 \%$ & $-7.7 \%$ & $-7.8 \%$ \\
\hline HFCS (per unit) & $-8.6 \%$ & $-5.4 \%$ & $-4.9 \%$ & $-4.4 \%$ & $-3.9 \%$ & $-3.8 \%$ & $-3.7 \%$ & $-3.9 \%$ \\
\hline
\end{tabular}

